\title{
Scrambling: Nontriggered Chain Formation in OV Languages
}

\author{
Hubert Haider \\ Salzburg University
}

Inger Rosengren

Lund University

In this paper we argue for the following properties of clause-bound scrambling, as they are manifested in German. First, scrambling presupposes head-final projections. Only selected constituents, notably arguments, scramble, the reason being that phrases selected by a head have a unique base order. Second, scrambling involves antecedent-gap dependencies with A-chain properties. Third, scrambling is overt and non-string-vacuous. Fourth, scrambling is syntactically optional, clause-bound, category neutral, and may apply to more than one phrase per clause. Fifth, scrambled elements remain transparent for extraction; they are licit binders and take scope.

Furthermore, we evaluate our conclusion that scrambling is contingent on the "OV" property by examining Yiddish, an uncontroversial scrambling Germanic language with controversial VO versus OV status. We argue that Yiddish is a variant of an OV language - thus allowing scrambling — and that it is the only Germanic language with alternative V-positions in a VP-shell structure, like Hindi, and, arguably, like Slavic languages."

\section{Introduction.}

Languages such as German allow for considerable word order freedom (also described as scrambling) in the "inner field" (Mittelfeld), that is, between the clause-initial position of the finite verb or the complementizer and the sentence-final position of verbs. Any possible

\footnotetext{
* We wish to thank two anonymous $J G L$ reviewers for their constructive comments and for pointing out various shortcomings in the previous version. Special thanks go to Marga Reis for valuable suggestions on various sections. The responsibility for remaining shortcomings remains ours, of course. We are very grateful to Mark Louden for his generous support in enhancing the readability.
}

(c) Society for Germanic Linguistics 
order of the three DPs in 1a is a grammatical serialization option in German. One of the five possible serializations of $1 \mathrm{a}$ is given in $1 \mathrm{~b}$.

(1) a. dass das Objekt dem Subjekt den ersten Platz that the object $_{\mathrm{NOM}}$ the subject $_{\mathrm{DAT}}$ the initial position $\mathrm{ACC}$ streitig macht competes-for 'that the object competes with the subject for the initial position'

b. dass dem Subjekt den ersten Platz das Objekt that the subject $_{\mathrm{DAT}}$ the initial place $\mathrm{ACC}_{\mathrm{C}}$ the object $_{\mathrm{NOM}}$ streitig macht competes-for

The first serialization is what is usually referred to as the normal or unmarked word order. All other word orders are not neutral and, as we shall argue, derive from the base order in 1a. However, none of these derived word orders is ungrammatical, though some may convey an infelicitous information structure for a given context. Deviance is pragmatic only.

Ross (1967), who coined the term "scrambling," placed it outside grammar proper and treated it as a stylistic rule. Chomsky does likewise in the minimalist program (1995) and later work (Chomsky 1998, 1999), mainly because of the optionality issue involved. ${ }^{1}$

Surprisingly, scrambling is still an unsettled issue in syntactic theory. Up to now all available theoretical approaches within a generative framework have found their (at least half-hearted) advocates (see Haider 1997a and Corver and van Riemsdijk 1997 for surveys). Scrambling has been analyzed in terms of: i. A- or A'-movement to functional Spec positions; ii. adjunction by $\mathrm{A}^{\prime}$-movement to positions outside the VP; or iii. freely base generated serializations. Recent attempts to implement scrambling within the framework of optimality theory have been made by Choi (1996, 1999), Büring (1996, 1997, 1999), and Müller (1999, 2000).

It is therefore worthwhile asking what might have prevented a general consensus on one of the solutions to emerge from this longstanding discussion. One reason is that scrambling is used to refer to a

\footnotetext{
${ }^{1}$ Chomsky (1995:324) suggests that operations such as extraposition and scrambling "may not really belong to the system we are discussing here as we keep closely to ... movement driven by feaure checking within the $\mathrm{N}-£$ computation," where $\mathrm{N}$ is a numeration and $£$ is LF.
} 
wide range of word order variation phenomena that, if reconstructed in a theory of grammar, do not constitute a consistent set. Another reason is the dominant idea within generative theory that (overt and covert) movement is triggered, hence there cannot exist such a phenomenon as "optional scrambling." We return to these approaches when discussing our own proposal. In particular, we assume, defend, and where possible, derive the following (hypo)theses:

i. Scrambling presupposes head-final projections and reorders selected items, notably arguments.

ii. Scrambling involves an antecedent-gap configuration with Achain properties. The position of the head-XP of the scrambling chain is contained within the (extended) lexical projection of the argument-taking head. Scrambling does not target Spec positions of functional heads. This holds for strictly clause-bound scrambling.

iii.The scrambled word order is distinct from the base order. Scrambling is overt and non-string-vacuous, that is, it has to be visible to reordering effects.

iv. Syntactically, scrambling is truly optional.

v. Yiddish is a special OV language and therefore is expected to allow scrambling.

In this paper we restrict ourselves primarily to data from Germanic languages, especially German. We further concentrate on verbal projections, although scrambling is found in head-final adjectival projections as well. $^{2}$

The paper is organized as follows. In section 2 we give a brief outline of our theoretical background assumptions, including an explication of our assumption as to why scrambling presupposes headfinal projections. In section 3 we define, discuss, and test our basic assumption that there are verb-class-specific base orders on which

${ }^{2}$ For lack of space we defer discussion of weak pronouns (see, however, the detailed analysis in Haider and Rosengren 1998). Their position at the far left of the clause (the so-called Wackernagel position) is the same kind of position as the one scrambled items target (that is, adjunction within the extended VP), but the regularities for pronoun movement are different. They are of no relevance in the present analysis. 
scrambling operates. In section 4 we derive the fact that scrambling applies to selected items only, notably arguments. Section 5 recapitulates the coverage of the facts under our analysis. In section 6 we argue that Yiddish is basically $\mathrm{OV}$ and not VO, whence scrambling is expected. Section 7 summarizes the paper.

\section{Theoretical Background.}

The main concern of this paper is an empirically adequate modeling of scrambling, paying attention to a nontechnical key issue of the minimalist program in its later versions (Chomsky 1998, 1999), namely optionality. Chomsky's $(1998,1999)$ ideas differ from those of Chomsky 1995 with respect to "bare output conditions": Covert movement is avoided and replaced by a matching operation that erases uninterpretable features of the target by matching them with features of the probe. As expected, these features are case and agreement features. Movement (or chain formation) is thus overt and feature-triggered. We argue that accounts in terms of feature-driven movement are inadequate for scrambling.

In our view, overt operations are allowed when grammar does not forbid them and are licensed either by structural requirements, such as one that requires the movement of the finite verb in root V2-clauses, or by the possibility to exploit them in a systematic way at the syntaxexternal interfaces. This we assume to hold for the EPP as well as for scrambling. ${ }^{3}$

Our starting point is a traditional CP-IP-VP structure for the Germanic VO languages. We do not see the need or justification for any inherently Agr-type projections. We assume only projections that may match the inflectional features of the verb, among others, TP. TP is regarded as the projection where tense features are checked, and SpecT is assumed to be the functional subject position in EPP-languages only, that is, not for German.

\footnotetext{
${ }^{3}$ In Chomsky 1999, the D-feature, proposed in Chomsky 1995, has changed to an EPP-feature, which turns into a general uninterpretable feature requiring visibility in order to be erased. See Rosengren 2000a, 2002 for a detailed discussion of recent literature building on this assumption. Rosengren argues that the EPP is a non-feature-driven parametrized visibility requirement on one of two functional Spec positions, SpecFin or SpecT, exploited at the semantic interface.
} 
For German we presuppose a minimal (overt) phrasal architecture for the clause that consists at least of a V-projection and a functional layer on top of it (see Haider 1997b). As for VP-the assumed domain of scrambling - the general (and uncontroversial) assumption is that the subject is base-generated within. Contrary to Kayne (1994, 1998), who assumes that $\mathrm{OV}$ is derived from $\mathrm{VO}$ by evacuation of all phrasal elements out of the head-initial VP or by remnant VP fronting, we assume that head-final projections are base-generated and that complex head-initial projections involve a shell structure resulting from head chaining (see Haider 1992, 1993, 1997d, and 2000a for a detailed, critical comparison). ${ }^{4}$ Under both accounts, movement to the right is not permitted, and under both, asymmetric c-command equals precedence.

The linear aspect of the head-complement relation, that is, $\mathrm{VO}$ versus $\mathrm{OV}$, is determined by the parametric direction of structural licensing and a universal restriction against merging to the right (see the Basic Branching Condition [BBC] in Haider 1992). Licensing to the left (regressive licensing) triggers the $\mathrm{OV}$ structure, licensing to the right (progressive licensing) the VO structure. The formulas in 2 illustrate the structural difference between the two projection options.
(2) a. $\left[\mathrm{XP}^{3}\left[\mathrm{XP}^{2}\left[\mathrm{XP}^{1} \mathrm{~V}\right]\right]\right]$
head-final
b. $\left[\mathrm{V}_{\mathrm{i}}\left[\mathrm{XP}^{3}\left[\mathrm{e}_{\mathrm{i}}\left[\mathrm{XP}^{2}\left[\mathrm{e}_{\mathrm{i}} \mathrm{XP}\right]\right]\right]\right.\right.$
head-initial

In $2 \mathrm{a}$ and $\mathrm{b}$ the XPs are in their base positions. The hierarchy, and consequently the base order, is determined by the semantic rank of the variables of the lexical entry. This ranking is mapped into the lexical-

\footnotetext{
${ }^{4}$ The LCA approach is shown to suffer from serious empirical and theoretical shortcomings (see Haider 2000a). First, its empirical coverage is very narrow. Once broadened, massive obstacles arise. Second, it falls short of a plausible account of what drives the movement machinery (put simply, why are not all languages VO?). Third, it lacks independent evidence for the complex derivational measures that have to conspire in order to derive an OV system. Fourth, there is a simpler, empirically more adequate, and theoretically less demanding account. Construction-based applications of the LCA system to an OV language (for example, Haegeman 1998) produce results that support Haider's head-driven approach rather than Kayne's phrase-driven approach to the OV-VO etiology (see Haider 2003).
} 
semantic A-structure and this, as a consequence of "discharge-bymerger," determines the base order of selected items, notably arguments. Since we do not want to complicate the theoretical exposition below, we focus on arguments only and return to selected nonarguments at the end of this section and in section 4 .

It is obvious that $2 \mathrm{~b}$ is more complex than $2 \mathrm{a}$. In $2 \mathrm{a}$ the head and each of its intermediate projections license to the left. Consequently, all XPs are within the identification domain of the head. This domain may be extended by additional positions adjoined to the projection. We refer to the minimal, nonextended part of the V-projection as the minimal argument projection complex" (MAC), that is, the minimal projection that contains the base positions of all arguments of the verbal head. Thus the MAC is the V-projection that minimally dominates the three argument positions (in the case of a three-place verb, of course).

The tree in 3 represents $2 \mathrm{a}$. A possible instantiation would be a double object construction of the type jemand schickt jemandem etwas 'somebody sends someone something'. Since the verbal head (and its projections) licenses to the left (indicated by the arrows), all XPs are in the identification domain of the head. No heads intervene. Technically, the XPs end up as either the direct complement of V or as adjoined to Vprojections, ${ }^{5}$ all of them, however, in strict locality to the head position (or its projection).

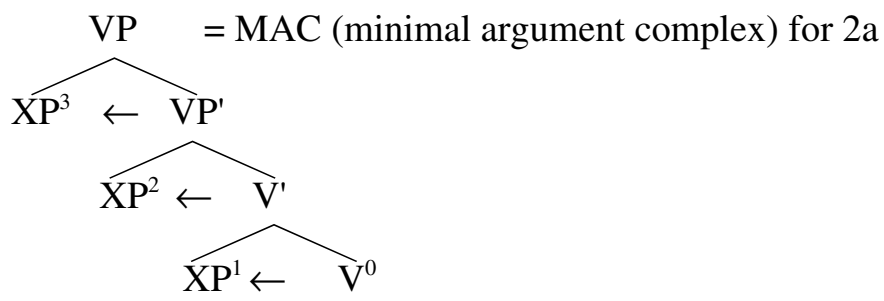

Let us turn now to $2 \mathrm{~b}$. The tree in 4 shows the structure of a Vprojection, again with three phrasal positions, and consequently three VP shells (possible instantiation: somebody sends someone something). Here, the verbal head, licensing to the right, has to be merged iteratively for each step of the projection, since, in its first merging position (= base

${ }^{5}$ We interpret adjunction as a structural notion. The adjunction position is a position merged with the projection of a syntactic category (daughter and sister of a segment of a [maximal] projection XP). We assume that all adjunction is to the left of a head (see Haider 1993, 2000a for a detailed discussion). 
position of $\mathrm{V}^{0}$ ), $\mathrm{V}^{0}$ would only license a single complement $\mathrm{XP}^{1}$. The overall result is a kind of Larsonian shell structure (cf. Larson 1988, Haider 1992). ${ }^{6}$

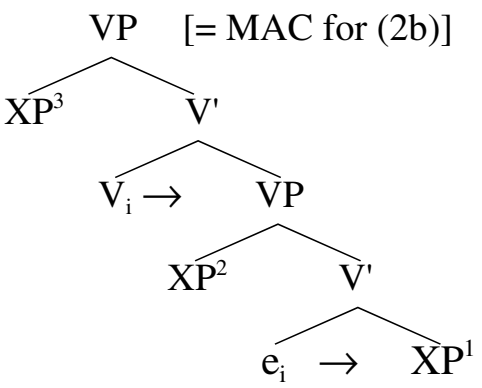

Two of the three arguments $\left(\mathrm{XP}^{2}, \mathrm{XP}^{1}\right)$ are within the directionality domain of $\mathrm{V}$, indicated by the arrows, but one is to the left, in Spec position of VP. This preverbal position is the VP-internal position of the external argument, that is, the position of the highest-ranked argument. It is a structurally licensed position (whose occupant needs to be functionally licensed by a higher functional head, since it is not in the proper directionality domain of its lexical head). $\mathrm{XP}^{2}$ is locally identified by the lowest head position and directionally licensed by the next-higher position, which is a position in the head-chain of the VP shell. Note that all XPs within the MAC are, by definition, in A-positions.

The structural reason for the basic difference between the VO and the OV structure is this: in the head-initial structure, the lowest head position cannot canonically license more than a single complement, namely its complement $\mathrm{XP}^{1}$. Further merging in the directional domain of the head, that is, to the right, would require right-adjunction and is excluded by the UG constraint against left-associative structures (see Haider 1992). Therefore, given that merging is possible only to the left, all resulting positions are outside the range of the directional licensing capacity of the verbal head. This requires that a new head position (for

${ }^{6}$ There is no need for invoking "inherently empty light" verbs, since we take shells to be iterative instantiations of the Spec-head-complement scheme. 
the same argument-discharging lexical head) be reinstantiated as a higher shell. This is the source of the shell structures. ${ }^{7}$

A closer look at the two structures shows us that, in principle, they have the same hierarchical organization. The difference between them is triggered by the inverse setting of the directionality parameter plus the universal merging constraint that excludes right-associative projections, that is, a ban on merging on the right-hand side. This difference, however, has consequences for scrambling. Genuine scrambling is possible only in OV languages. Why is this so? Let us first look at the following OV structure for the sake of explication.

We need to distinguish two cases. In the first, a scrambled XP-let us assume it is $\mathrm{XP}^{1}$ - targets a position in front of the base positions of all the arguments of $\mathrm{V}$, that is, on top of the MAC ( $\mathrm{XP}^{4}$ in the tree in 5). In the second case, the target position could be lower, $\mathrm{XP}^{3}$, for instance. In this case, the scrambled argument would be sandwiched between the base positions of arguments. In the latter case, scrambling would be MAC-internal.

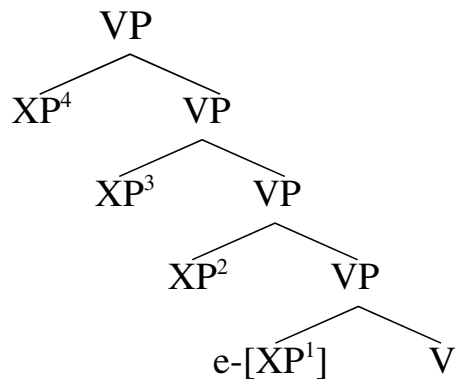

Note that in the first case $\mathrm{XP}^{3}$ (and in the second case $\mathrm{XP}^{2}$ ) cannot be the trace position, since scrambling then would be string-vacuous, which is not permitted, see section 5.3. In the first case, the trace could be either in $\mathrm{XP}^{1}$, as chosen here, or in $\mathrm{XP}^{2}$; in the second case it can be only in $\mathrm{XP}^{1}$.

\footnotetext{
${ }^{7}$ Note that it is possible in both trees to freely adjoin adverbials. This would mean one more XP adjoined to the upper VP, that is, to the MAC. We do not follow Cinque's (1999) proposal that sentential adverbials are in Spec positions of functional heads (see Haider and Rosengren 1998, Rosengren 2000b, 2003, and Haider 2000b, for a detailed discussion). Instead, we entertain the traditional assumption that all adverbials are adjuncts.
} 
As mentioned above, technically, all phrases are adjoined to the projection line (by merger). The implications for scrambling are obvious, given that scrambling is always the result of a phrase being merged more than once within the $\mathrm{V}$-projection. ${ }^{8}$ Adjunction by merger extends the identification domain of the head by adding a node to the projection line. The scrambled constituents are nevertheless linked to the head in its licensing domain. Consequently, they are by definition links in an Achain, and the head and the copy are within the same domain. Linking applies to the head of the chain, identification to the foot. Thus we define scrambling as chain formation within the (extended) VP, where the head and the foot of the chain (that is, the copy) occupy positions within the identification domain of the head. If, however, $\mathrm{XP}^{4}$ is a nonselected element (an adverbial, for example), $\mathrm{XP}^{4}$, as an element in the directional licensing domain of the verb, is structurally licensed but not identified by $\mathrm{V}^{0}$.

Let us now consider how scrambling would be realized in a headinitial V-projection. Take, for instance, the VO structure in 6. Again, we need to distinguish the two cases discussed above. The first case involves scrambling across $\mathrm{XP}^{3}$, that is, merger with the complete MAC. In this case, $\mathrm{XP}^{4}$ would be the antecedent of a trace either in the sister position of the head (here, $\mathrm{XP}^{1}$ ) or in a higher position (here, $\mathrm{XP}^{2}$ ). The second case is one of VP-internal scrambling. Here, two possibilities have to be distinguished. We demonstrate that all three possibilities are ruled out by independently motivated restrictions and that this is the reason why scrambling is not found with head-initial projections.

${ }^{8}$ Note that here we use the tools of the minimalist program for expository purposes. For explanatory reasons, though, we prefer a representational view. Scrambling in the representational view is the need to project a gap (that is, a trace) for an XP encountered in the licensing domain of the head in a position not conforming to the base order determined by the head. In the derivational view endorsed by minimalism, scrambling requires the counterintuitive assumption of multiple mergers of a given argument. In this view, it would therefore be legitimate to ask whether an argument could be merged more than twice (viz., iterated scrambling). This question does not arise in the representational view. There is only the distinction between base order and nonbase order. So there is always only a chain with two links, namely a base position and a scrambled position. 
(6)

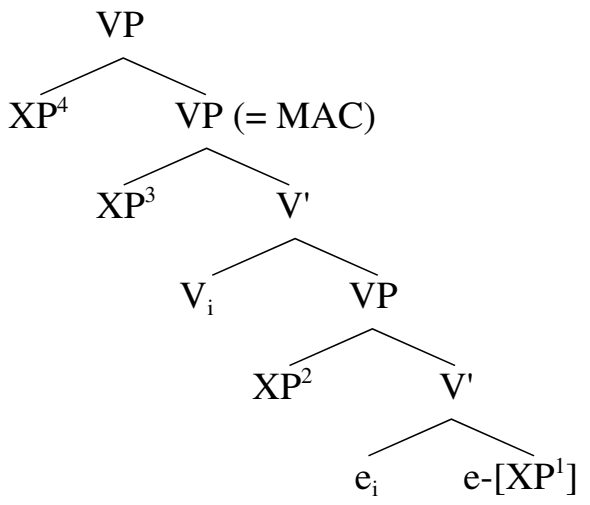

Let us start with the first case. $\mathrm{XP}^{4}$ is neither within the directionality domain of the head nor is it in a strictly local relation to the head, since it is adjoined to the VP with an XP already in its Spec. Thus it cannot be identified by the head, either by directionality or by locality. In this way this position is different from the scrambling positions within a headfinal V-projection since these are head-identified positions. $\mathrm{XP}^{4}$ could only be an adjoined $\mathrm{A}^{\prime}$-position. Note once again that, alternatively, it could be an adjoined adverbial.

Let us now consider the second case. Here we need to distinguish two subcases, namely scrambling by adjunction to a subtree (as in 7a), or scrambling into a potential argument position within the directionality domain (7b). In the latter case, a position in the VP-shell would have to host the scrambled element.

(7) a. $*\left[V_{\mathrm{i}}\left[\mathrm{YP}_{\mathrm{j}}\left[\mathrm{XP}\left[e_{\mathrm{i}} \mathrm{e}_{\mathrm{j}}\right]\right]\right]\right]$

b. $*\left[V_{\mathrm{i}}\left[\mathrm{YP}_{\mathrm{j}}\left[e_{\mathrm{i}}\left[\mathrm{XP}\left[e_{\mathrm{i}} \mathrm{e}_{\mathrm{j}}\right]\right]\right]\right]\right]$

It is easy to see why the first case, $7 \mathrm{a}$, is ruled out independently. The independent restriction at work in $7 \mathrm{a}$ is the very same restriction that rules out any material that intervenes between the verb and the licensee in the lower VP shell (namely, XP in 7a). This case is a subinstance of the general restriction against interveners in the argumental VP-shells. Descriptively, this amounts to the ban on intervening material between a higher verb position and an argument that is not identified as an argument. 8a-c are special cases of this general restriction.

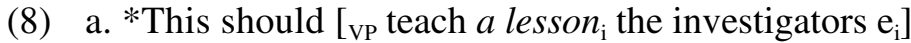

b. *This should [vp teach immediately the investigators a lesson] 


\section{c. *This should [vp teach as an example the investigators a lesson]}

What is responsible for the exclusion of $7 \mathrm{~b}$ ? That is, what forbids the formation of a chain between two argument positions within the directional identification domain in a head-initial projection?

From an empirical perspective, a side-look at Icelandic is helpful. First, in Icelandic, arguments do not scramble to the left of the verbal head by means of left-adjunction. Left-adjunction to the VP would create a position outside the directional licensing domain. Second, free scrambling within the postverbal part of the VP is not possible either, despite the richness of Icelandic case morphology. From a theoretical perspective, $7 \mathrm{~b}$ raises a broader issue, namely, why is not possible in head-initial VPs to add extra shells in order to make space for scrambling? The answer is this. Shell-formation is driven by the discharge of the argument structure. Once the argument structure has been discharged (by merger, resulting in the MAC projection), the VP is complete and could be extended only by adjunction. This brings us back to $7 \mathrm{a}$ and the difference between $\mathrm{VO}$ and $\mathrm{OV}$.

The base structure of $7 \mathrm{~b}$ would be $9.7 \mathrm{~b}$, repeated as $10 \mathrm{a}$, could be generated only by projecting an extra shell and then moving the YP to the Spec of the extra shell. However there is no license for creating an extra shell. YP could only move to a higher functional Spec $(10 b)^{9}$ or be adjoined. In either case, the result would not count as a case of scrambling (that is, chain formation within the identification domain of the verbal head).

(9) $\quad\left[{ }_{\mathrm{vP}} \mathrm{XP}\left[V^{0} \mathrm{YP}\right]\right]$

(10) a. $*\left[{ }_{\mathrm{VP}} \mathrm{V}_{\mathrm{i}}\left[\mathrm{YP}_{\mathrm{j}}\left[e_{\mathrm{i}}\left[\mathrm{XP}\left[e_{\mathrm{i}} \mathrm{e}_{\mathrm{j}}\right]\right]\right]\right](=7 \mathrm{~b})\right.$

\footnotetext{
${ }^{9}$ Collins and Thráinsson (1996:417) claim that for ditransitive verbs of the givetype class only, with [vp V-DAT-ACC] base order, the order [vP V-ACC-DAT] is alternatively possible (with stress on the Dative DP). Holmberg and Platzack (1995:213) argue that this alternation is between two independent argument structure formats, that is, that the alternative orders are alternative base orders without a derivational relation. We follow Holmberg and Platzack, since this approach avoids massive overgeneration when admitting scrambling for Icelandic.
} 
b. $\left[\mathrm{F}^{1} 1 \mathrm{~V}_{\mathrm{i}}\left[{ }_{\mathrm{FP} 2} \mathrm{YP}_{\mathrm{j}}\left[\mathrm{F}_{2} e_{\mathrm{i}}\left[\mathrm{VP} \mathrm{XP}\left[e_{\mathrm{i}} \mathrm{e}_{\mathrm{j}}\right]\right]\right]\right]\right]^{10}$

This completes the discussion of the different scrambling possibilities within verb-initial versus verb-final projections. Up to this point we have tacitly assumed that only arguments may scramble. Since the precondition for scrambling is that the scrambled element has a lexically determined unique syntactic base position and needs to be identified by a head, arguments are prototypical candidates for scrambling. For DPs, with the exception of the external argument, identification involves case-licensing by the head within the projection of the argument-providing head. A lexical head can check for a single case value per case category, that is, one structural case, one lexical case, and one oblique (for example, prepositional) case. Arguments in positions within the identification domain of the lexical head are L-related positions. They are checked in their overt position in both systems. In an OV structure, this position may, however, be a scrambling position. This is not possible in a VO structure (see the discussion above). Since the entire chain is in the domain of the lexical head, we expect that the scrambled constituent does not differ from the unscrambled one with respect to grammatical factors conditioning opacity of extraction, and that it behaves in principle as any base generated element with respect to binding.

As for selected modifiers, we would ceteris paribus expect them to scramble for the same reason as arguments scramble: they have a semantically determined syntactic base position. Additional, intervening factors, however, prevent scrambling (except in one case). We return to this issue in section 4.

Free (that is, nonselected) adverbials do not scramble, since by definition they are not selected. We contend that the distribution of these adverbials is best described in terms of (alternatively available) positions in the syntactic tree, and their scope conditions that determine the actual position (compare Neeleman and Reinhart 1997, Haider 2000b, Rosengren, 2000b, 2003; for competing claims, see Maienborn 1996 and Frey and Pittner 1998).

Summing up, let us consider once more the status of scrambling in the generative framework we assume above. We claim that scrambling is free chain formation within the head-final VP and is therefore limited to

10 This structure could, for instance, capture clause-internal V2-structures in Icelandic, with a topicalized YP. 
OV languages. The reason for this is that the position of the scrambled argument must have the same linking relation to the head as its trace has, the result being an A-chain. This is only possible in languages with a regressive setting of the directionality parameter, that is, in $\mathrm{OV}$ languages, and not in VO languages.

From these assumptions, two main properties of scrambling follow. First, scrambling, not being triggered by any syntactic feature, is syntactically truly optional. In other words, it is a system potential. It is allowed where grammar does not forbid it, and syntax will not forbid it in OV languages. Second, scrambling is exclusively syntactic, that is, the scrambled chain has no meaning or function per se. It is, however, exploited at the interface between syntax and semantics/pragmatics. Thus, scrambling gives rise to new c-command relations, resulting in scope alternations and new binding relations, as well as variable information structure settings based on variable focus/background organizations. ${ }^{11}$

This difference between $\mathrm{OV}$ and $\mathrm{VO}$ languages is crucial to understanding why German and Dutch, but not English and the Scandinavian languages, allow scrambling. ${ }^{12}$ In the following sections we discuss two basic issues in connection with our definition of scrambling in a more detailed manner. First, we show that different thematic structures give rise to different base orders and consequently to different scrambling orders. Second, we argue that scrambling should be modeled in terms of chains rather than base-generated, since there is independent evidence for traces.

\section{Base Order as a Function of the Projection of Thematic Structure.} 3.1. Verb Classes with Different Base Orders in German.

As mentioned above, our principal assumption is that the base order is a direct reflex of the asymmetric ranking order of the variables in the

\footnotetext{
${ }^{11}$ For lack of space, we do not discuss these functions in any systematic way. For further details with regard to focus/background relations, we refer the reader to the relevant literature, among others, Jackendoff 1972, Gussenhoven 1984, Culicover and Rochemont 1983, Selkirk 1984, Rochemont 1986, Uhmann 1991, Hetland 1992, Rosengren 1993, 1994, and Winkler 1997. See also Haider and Rosengren 1998.

${ }^{12}$ As for Dutch, scrambling is highly restricted, due to the lack of distinct case marking. We return to this in section 5.4.
} 
lexical entry (that is, arguments and selected modifiers). The ranking hierarchy is mapped onto an asymmetric syntactic structure. For ease of reference, we refer to the structure in the lexicon as "thematic structure," and the syntactic structure "c(onstituent)-structure." A higher-ranked argument or modifier in the thematic structure ends up in a higher position in the c-structure. 11 is but an illustration of the hierarchyconserving mapping relation between the asymmetric thematic structure and the asymmetric c-structure.

(11) thematic structure $\mathrm{H}^{0}:<\mathrm{A}<\mathrm{B}<\mathrm{C}>>>$ c-structure (head-final)

[ A [ B [ $\left.\left.\left.\mathrm{C} \mathrm{H}^{0}\right]\right]\right]$

The ranking of the argument positions in the thematic structure of an individual item is not idiosyncratic; rather, it is determined by the semantics, or more correctly, by the conceptual structure, of the verbal head (Bierwisch 1988, Haider 1993, Wunderlich 1997). The conceptual structure determines the ranking of the argument positions in the thematic structure that is mapped directly into syntactic structure. The following German morphosyntactic patterns are considered to be possible base orders for nominal arguments in German (see Haider 1992, 1997a).

(12) a. NOM > ACC:

b. $\mathrm{ACC}>\mathrm{NOM}:^{13}$

c. $\mathrm{NOM}>\mathrm{DAT}$ :

d. DAT > NOM: anfassen, bedauern, interpretieren, ...

'touch, regret, interpret, ...' ängstigen, beeindrucken, interessieren, ... 'frighten, impress, interest, ...' helfen, gratulieren, widersprechen, ... 'help, congratulate, oppose, ...' gefallen, fehlen, imponieren, ... 'be pleasing to, lack, impress,...'

\footnotetext{
${ }^{13}$ The subject of the verbs in this class receives a "target and cause of emotion" interpretation (Pesetsky 1994). If an agent-only interpretation is chosen, the verb must be assigned to the class 12a. If target and cause of emotion coincide, the rank of the nominative argument is determined by the lower-ranked occurrence of the target argument. Its nominative status is determined by the higher occurrence in the lexical-argument structure, namely, the cause argument. The coincidence of cause-and-target results in a nominative DP in a lower argument position than the sister argument.
} 

e. NOM > DAT > ACC: anvertrauen, verbieten, zeigen, ... 'entrust, forbid, show, ...'
f. NOM > ACC > DAT: aussetzen, unterordnen, widmen, ... 'expose, subordinate, devote, ...'

The verbs in $12 \mathrm{a}-\mathrm{f}$ are all verbs that require haben 'have' as an auxiliary, hence the patterns $12 \mathrm{~b}$ and $\mathrm{d}$ cannot be explained away as an ergativeunergative effect.

We assumed above that scrambling involves chain-formation, that is, antecedent-trace configuration, where the scrambled element is in the head position of the chain and the trace is in the foot position, that is, in the base position of the scrambled argument. From the assumption that there are different basic serializations of arguments it follows that a given order of arguments and selected modifiers may be a base order for one verb type but the result of scrambling for another verb type.

We are, of course, not content to just stipulate the above verb groups. In section 3.3. we discuss several independent types of data that are best accounted for if scrambling involves chain-formation of the above assumed verb classes. One example of such data occurs when focus spreading is absent if the structural nuclear stress position is a trace, and therefore empty. A second group of data involves reconstruction effects found with a scrambled word order but not with an unscrambled one. These types of data thus help us to identify the base order of specific verbs. As is demonstrated below, the above verb classes do indeed exist. But first let us briefly touch on two principled alternative attempts to capture the variant serialization patterns for NOM, DAT, and ACC in German.

\subsection{Other Accounts of Base Order in German.}

Below are two alternative accounts of German base order. The first approach we mention only in passing, because it multiplies base orders, but the second we discuss in greater detail because it involves challenges for the approach to base orders sketched in the preceding subsection.

i. Base-generated alternative syntactic orders (e.g., Haider 1984, Miyagawa 1997, for VP-internal variation); unique ordering restored on LF (Boskovic and Takahashi 1998; Fanselow 1998). 
ii. Competition models of base (Heck 2000) and surface serializations, including animacy as ordering effect (Müller 1999; see Müller 2000 for a survey of optimality theoretic approaches; arguments against competition models can be found in Lenerz 1999).

The approaches in i are "trace-free" in the surface structure since variation in order is seen as the result of alternative serialization options and not as the result of movement or chain formation. Consequently, any of the alternative orders are independently generated base orders. The arguments for specific overt base orders presented in this section and in section 3.3. are arguments against these theses.

The positions in ii elevate descriptive notions such as "animacy"14 (and "definiteness") to the status of primary factors of grammar. Animacy is, however, a bad candidate for a primary ordering factor. It is a conceptual distinction whose interface with grammar needs to be clarified before it can be invoked as more than a descriptive label. In our account, animacy comes into play in the mapping between conceptual structure and thematic structure. Animacy is a feature of experiencers and possessors. If the conceptual organization involves these relations, the corresponding argument position will end up in the appropriate ranking configuration. It should be clear, however, that animacy is but a reflex of a behind-the-scenes interface and not a syntactically active category. Empirical evidence from two areas supports this. First, since animacy is not a primary grammatical factor, we should not be surprised to find observational inadequacies. Second, the animacy premise is in conflict with comparative evidence.

Regarding the first type of evidence, "animacy" tends to be confused with the different conceptual organization of DAT-ACC (experiencer/possessor-theme) versus ACC-DAT (theme-source/goal) verbs. If conceptual distinctions are overlooked, misguided data interpretations result. Heck (2000:453) juxtaposes $13 \mathrm{a}$ and $13 \mathrm{~b}$ as "evidence" of the animacy effect. In each sentence the object denoting an animate referent precedes the other, inanimate object.

${ }^{14}$ See Heck 2000:452. If coargument objects differ in the value for "animacy," a [+animate] DP precedes a [-animate] DP. 
(13) a. dass er der Mutter ${ }_{\mathrm{DAT}}$ das Sorgerecht $_{\mathrm{ACC}}$ entzogen hat that he the mother the custody deprived-of has 'that he deprived the mother of custody'

b. dass er ein Kind $_{\mathrm{ACC}}$ einem schlechten Einfluss DAT $_{\text {DA }}$ that he a child a bad influence entzogen hat taken-away-from has 'that he removed a child from a bad influence'

This account overlooks the fact that the verb entziehen 'deprive of/take away from' is used differently in 13a and b, respectively. But note that different lexical-conceptual meanings result in different Astructure rankings. In 13a the dative argument is a possessor relation, while in $13 b$ it is in a source relation. Source relation is ranked lower than a theme, a possessor relation is ranked higher. Consulting a translation dictionary suffices to assure oneself of the different conceptualizations that are paired with different translational equivalents (that is, 'deprive of' vs. 'take away from'). If animacy were a syntactic factor, we would expect that in the unmarked order the DP that denotes an animate referent would always precede inanimate ones, regardless of the case of the animate referent. This is not what we find, however, as the examples in 14 demonstrate. (Note that sentence stress in the examples below is indicated by italicization. Wide focus is denoted by "WF" and narrow focus by "NF".)

(14) a. Er hat das erste Gedicht ${ }_{\mathrm{ACC}}$ seiner Mutter $_{\mathrm{DAT}}$ gewidmet. he has the first poem to-his mother dedicated 'He dedicated the first poem to his mother.'

b. Er hat seiner Mutter $\mathrm{i}_{\mathrm{i} / \mathrm{DAT}}$ das erste Gedicht $\mathrm{ACC}_{\mathrm{i}} \mathrm{e}_{\mathrm{i}}$ gewidmet. he has to-his mother the first poem dedicated 'He dedicated to his mother the first poem.'

c. dass er einem Haus DAT $_{\text {einen neuen Besitzer }}$ ACC $_{\text {verschaffte }}$ WF that he for-a house a new owner obtained 'that he obtained for a house a new owner'

d. dass er einen neuen Besitzer ${ }_{\mathrm{ACC}}$ einem Haus ${ }_{\mathrm{DAT}}$ verschaffte $\mathrm{NF}$ that he a new owner for-a house obtained 'that he obtained a new owner for a house' 
The verb widmen 'dedicate (to)', with the dative in the goal relation, violates the supposed animacy-determined order, as does the verb verschaffen 'obtain (for)'. In 14a the animate goal dative follows the animate theme, while in $14 \mathrm{c}$ the inanimate possessor precedes it. The criterion for assuming that $14 \mathrm{a}$ and $14 \mathrm{c}$ reflect neutral word orders is the fact that they both allow focus spreading. This is discussed in more detail in the next section. Scope reconstruction confirms this result (cf. Frey 1993); compare the examples in 15.

(15) a. Er hat fast alle Gedichte mindestens drei Frauen DAT he has almost all poems at-least three women gewidmet. dedicated 'He dedicated almost all (his) poems to at least three women.'

b. Er hat fast allen Frauen ${ }_{\text {DAT }}$ mindestens drei Gedichte he has almost all women at-least three poems gewidmet. dedicated 'He dedicated at least three poems to almost all women.'

In $15 \mathrm{a}$ the scope is unambiguous. In $15 \mathrm{~b}$, however, a wide-scope reading of the existential quantifier is possible. This is expected under a movement account if the dative is moved across the preceding quantified DP, leaving a gap in the scope of the universal quantifier. Note, however, that the animacy-driven account yields the wrong prediction. 15a violates animacy. If this violation is seen as the effect of a derivational step that follows the animacy check, 15a would count as a derived structure, and hence 15 a should be ambiguous with respect to scope.

As for the second point, comparative evidence points to the same conclusion, namely that animacy is not a primary syntactic trigger of serialization and that it does not overrule the order generated by the projection of the argument structure. In Haider 1992 it is pointed out that the English (and also Icelandic ${ }^{15}$ ) counterparts of verbs with ACC-DAT order show the same rigid order. In the absence of a morphologically

15 It is worth emphasizing that Icelandic has V-class-dependent base orders (Kress 1982, Yip, Maling, and Jackendoff 1987), too. In Icelandic, variant base orders, however, are easier to identify than in German, because the language does not scramble freely. 
distinctive dative case in English, the corresponding arguments are coded as prepositional objects.

(16) a. He dedicated his first poem to his mother/to her.

b. *He dedicated his mother/her his first poem.

c. We do not envy the leading nation/them their bright president.

d. *We do not envy their bright president to the leading nation/to them.

Since the "dative" argument of envy is not compatible with a goal interpretation, the alternation with a PP object (16b) is ruled out. In German, widmen 'dedicate' is an ACC-DAT verb, but neiden 'envy' is a DAT-ACC verb.

Proposals based on a "competition model" have in common that they combine grammar theory with optimality theory. For a detailed survey and discussion of these proposals we refer to Müller 2000. After discussing and rejecting other optimality theoretic accounts, ${ }^{16}$ Müller, in his own optimality approach based on data from Müller 1995:162f.,195f., argues for subject $>$ direct object $>$ indirect object as the unscrambled surface word order for German. The main evidence for this assumption is that a DAT argument cannot bind an anaphoric ACC, as shown in 17 (from Müller 2000:244).

(17) a. dass man die Gäste ${ }_{\mathrm{ACC}}$ einander vorstellte that one the guests one-another introduced 'that the guests were introduced to one another'

b. *dass man den Gästen ${ }_{\mathrm{DAT}}$ einander vorstellte that one the guests one-another introduced

However, the evidence from 17 is less clear than one would like since a dative indeed can bind anaphors, but only if they are not coarguments, as illustrated in $18 \mathrm{a}, \mathrm{b}$. Furthermore, $18 \mathrm{c}$ shows that a

${ }^{16} \mathrm{He}$ concludes his overview with the statement that optimality theory in its standard form cannot account for the facts of the German word order. The result is either undergeneration or the need for nontrivial modifications of OT (Müller 2000:256). The optimality theoretic account is a trace-free account. Since we claim that there is evidence for traces, we will not go into OT-specific details here. 
dative may be the antecedent of a self-anaphor. This is in line with Reinhart and Reuland's (1995) approach to reflexivization: "A predicate is reflexive iff two of its arguments are coindexed" (1995:247). This definition is met by 17 , but not by $18 a, b{ }^{17}$

(18) a. Ich habe den Gästen ${ }_{\mathrm{i} / \mathrm{DAT}}$ [von einander ${ }_{\mathrm{i}}$ ] erzählt. I have the guests of each-other told 'I told the guests about each other.'

b. Ich habe den Gästen $\mathrm{i}_{\mathrm{i} \text { DAT }}[\text { Gerüchte über einander }]_{\mathrm{ACC}}$ erzählt. I have the guests rumors about each-other told

c. Ich habe dem Gast ${ }_{\mathrm{DAT}}$ sich ??/*(selbst) als Kandidaten

I have the guest REFL self as candidate empfohlen.

recommended

Both the reflexive sich as well as the reciprocal einander are morphologically inert. They do not show any case differentiation and are bare markers of reflexivity or reciprocity. The restriction against a dative antecedent seems to be a restriction against a lexically case-specified argument binding a coargument with structural case, that is, without lexical case specifications. Hence it applies only to reflexive/reciprocal predicates, that is, as in 17 but not in 18a,b. In 18a,b we find reflexive constructions, but the predicate is not reflexive in the technical sense because the coindexed items are not coarguments.

But the most damaging evidence for NOM $>$ ACC $>$ DAT as the base order for double object constructions comes from Dutch. First, the pronominal order cannot be used as evidence for a general base order for the simple fact that Dutch shows the very same restriction for pronominal arguments as German. They are ordered in the sequence $\mathrm{NOM}>\mathrm{ACC}>\mathrm{DAT}$. On the other hand, Dutch has a rigid NOM $>$ DAT $>$ ACC order for nonpronominal arguments. Since Dutch forbids scrambling of DPs across one another (see section 5.4.), this is evidence for the independence of the respective serialization triggers involved. Furthermore, it is evidence against a NOM $>$ ACC $>$ DAT base order for surface DAT > ACC order in Dutch and German. As in English, the only permissible relative order for nonpronominal double objects in Dutch is

${ }^{17}$ It parallels a restriction found in Dutch (Reinhart and Reuland 1993:242):

(i) Max haat zichzelf/*zich/ hem. Max hates himself/(him)self/him 
NOM $>$ DAT > ACC. In Icelandic the very same verb class has DAT > ACC order. There is no reason to assume that in each case this is a masked inversion of a base order.

\subsection{How to Identify a Scrambled Order.}

In this section we test our basic assumption that different thematic structures give rise to different verb classes, in turn resulting in different overt base case orders in c-structure. What is needed is an empirically reliable test criterion allowing us to decide whether a given serialization is the result of scrambling or whether it is a base order. Moreover, the test should be sensitive to antecedent-gap constellations that accompany scrambling, thereby supporting our assumption that scrambling involves chain formation.

One diagnostic with the desired property is provided by the phonology-syntax interface. The diagnostic property that we exploit below is the availability of a wide focus potential under a specific accentuation pattern. A second area of evidence is a property of the syntax-semantics interface, namely the computation of scope. Here we exploit the scope principle (see Frey 1993, Aoun and Li, 1993) that gives rise to scope ambiguities if chains cross.

\subsubsection{Focus Potential.}

The standard view within generative theory has been and still is that maximal or wide focus (that is, where the whole utterance is focused) is possible only in clauses where the focus exponent (namely, the constituent carrying the nuclear accent) is in base position and in the sister position of the head. ${ }^{18}$

In order to be a felicitous answer to a question like "What has happened?" an utterance normally requires a wide focus potential because the whole response utterance is in focus. Scrambling of the most deeply embedded argument destroys this constellation, since the most deeply embedded A-position would then be a trace, and traces cannot be

${ }^{18}$ Since we, for the time being, are only interested in arguments, here we just look at clauses where an argument is the expected focus exponent (the prototypical case, in fact). Note also that the reading need not be narrow in the sense that only the focus exponent is focused: there may be possible readings with a restricted focus domain (see Rosengren 1993, 1994). This is, however, of no relevance for the present issue. 
accented. A nuclear accent on any other position yields only a narrow or restricted focus domain.

In the above framework with variant basic word order patterns, a NOM, DAT, or ACC may be the focus exponent in a wide focus reading whenever the argument is the sister complement of the verbal head. With this in mind, we may test utterances for the potential extension of their focus by examining them in the question context mentioned above. Whenever the focus of a construction with a V-adjacent argument is restricted (rendering the utterance an inappropriate response in the given context) we know that the expected focus exponent in structural terms is not the closest argument to the verb. A closer argument must have left a trace in its base position. Hence, this test tells us not only which one of two alternative constellations is the base constellation, but also that the scrambled phrase has left a trace. Let us look at some representative examples. The examples in 19 contrast a verb with NOM > ACC base order (interpretieren 'interpret') and one with ACC $>$ NOM base order (interessieren 'interest'). (Again, italicization shows sentence stress.)

(19) a. dass Linguisten ${ }_{\mathrm{NOM}}$ Balladen $_{\mathrm{ACC}}$ interpretieren WF that linguists ballads interpret 'that linguists interpret ballads'

b. dass Balladen ${ }_{\mathrm{i} / \mathrm{ACC}}$ Linguisten $_{\mathrm{NOM}} \mathrm{e}_{\mathrm{i}}$ interpretieren $\mathrm{NF}$ that ballads linguists interpret

c. dass Linguisten ${ }_{\mathrm{ACC}}$ Balladen $_{\mathrm{NOM}}$ interessieren WF that linguists ballads interest 'that ballads are of interest to linguists'

d. dass Balladen $\mathrm{i}_{\mathrm{NOM}}$ Linguisten $_{\mathrm{ACC}} \mathrm{e}_{\mathrm{i}}$ interessieren $\quad \mathrm{NF}$ that ballads linguists interest

The utterances in 19a,c would be felicitous answers to the above questions, whereas $19 \mathrm{~b}, \mathrm{~d}$ would be appropriate responses to a question like "Who interprets ballads?" (for 19b) and "Who do ballads interest?" (for 19d). In 19a,c the focus exponent actually is the closest argument to the verbal head in surface structure, the result (as expected) being a wide focus. In 19b,d the DP carrying the nuclear accent is no longer closest to the verbal head (a trace intervenes) and the focus, therefore, is narrow. Equally felicitous answers to the "narrow" questions are, by the way, the sentences in 19a,b, respectively, but with the nuclear accent on the first DP. Compare the examples in 20. 
(20) a. dass Linguisten $\mathrm{NOM}_{\mathrm{NO}}$ Balladen $_{\mathrm{ACC}}$ interpretieren 'that linguists interpret ballads'

b. dass Linguisten ${ }_{\mathrm{ACC}}$ Balladen $_{\mathrm{NOM}}$ interessieren $\mathrm{NF}$ 'that ballads are of interest to linguists'

In both cases, $19 \mathrm{~b}, \mathrm{~d}$ and $20 \mathrm{a}, \mathrm{b}$, we thus get narrow focus. This parallelism is evidence for the existence of a trace in 19b,d. That is, the trace in the base positions in $19 \mathrm{~b}, \mathrm{~d}$ accounts for the fact that the nuclear accent on Linguisten gives rise to narrow focus. The same happens, of course, when the base order is preserved with the nuclear accent on Linguisten (as in 20a,b). ${ }^{19}$ Let us now look at some examples (21) with DAT $>$ ACC and ACC $>$ DAT.

(21) a. Es hinterließ jemand einer Frau ${ }_{\mathrm{DAT}}$ eine Nachricht $\mathrm{ACC}_{\text {. }}$ WF there left someone a woman a message

'Someone left a woman a message.'

b. Es hinterließ jemand [eine Nachricht] $]_{i / A C C}$ einer $\operatorname{Frau}_{\mathrm{DAT}} \mathrm{e}_{\mathrm{i}} . \quad \mathrm{NF}$ 'Someone left a woman a message.'

c. Ein Lehrer setzte einen Schüler ${ }_{\mathrm{ACC}}$ einer großen Gefahr $r_{\mathrm{DAT}}$ aus. WF a teacherset a pupil a great danger out 'A teacher exposed a pupil to great danger.'

d. Ein Lehrer setzte [einer großen Gefahr $]_{\mathrm{i} / \mathrm{DAT}}$ einen Schüler $_{\mathrm{ACC}} \mathrm{e}_{\mathrm{i}}$ aus.

'A teacher exposed a pupil to great danger.'

The basic difference between the two verb classes is obvious. In the DAT $>$ ACC class, the dative argument is typically an experiencer, hence an animate denotation. In the ACC > DAT class, the dative-marked argument is frequently a nonanimate denotation, since it typically codes for a goal or source relation. This difference-experiencer versus

19 This, of course, does not mean that $19 \mathrm{~b}, \mathrm{~d}$ and $20 \mathrm{a}, \mathrm{b}$ are informationally equivalent. Obviously, 19c,d succeed in keeping the nuclear accent as far to the right as possible, whereas the examples in $20 \mathrm{a}, \mathrm{b}$ are informationally more marked (although syntactically unmarked) by not using this possibility. Scrambling, thus, is a means to differentiate between a wide and narrow focus and still satisfy what has been called the Nuclear Stress Rule (NSR), which specifies that the nuclear accent prefers a position as far back in the clause as possible (see, for example, Selkirk 1984:151). 
goal-is reflected in the difference in argument ranking in the thematic structures of the respective verbs. Note once again that animacy is not the grammatical trigger for the word order differences (see the discussion in section 3.1. above). Consequently, neutralized animacy has no effect on the base order in the DAT > ACC class either; compare the examples in 22 .

(22) a. dass er dem Buch DAT $_{\text {das }}$ Vorwort ${ }_{\mathrm{ACC}}$ hinzufügte WF that he the book the preface added 'that he added the preface to the book'

b. dass er [das Vorwort $]_{\mathrm{i} / \mathrm{ACC}}$ dem Buch $_{\mathrm{DAT}} \mathrm{e}_{\mathrm{i}}$ hinzufügte NF 'that he added the preface to the book'

c. dass er der Firma ${ }_{\mathrm{DAT}}$ den Finanzchef ACC $_{\text {ACW }}$ abwarb that he the company the financial-manager lured-away 'that he lured the financial manager away from the company'

d. dass er [den Finanzchef] $]_{\mathrm{i} / \mathrm{ACC}}$ der Firma DAT $_{\mathrm{i}}$ abwarb NF 'that he lured the financial manager away from the company'

The focus test supports our assumption that there are different base orders and therefore different scrambling orders. Of course, this test is intrinsically limited, since it is applicable only in the A-position closest to the verb. In the next section, we test the results by considering the scope properties.

3.3.2. Scope Ambiguities As the Result of Scrambling.

In this section we show that scrambling can lead to scope ambiguities if the scrambling chain crosses a quantifier c-commanding the base position of the scrambled item but not the landing site (see Frey 1993). Let us begin with the data in 23 .

(23) $Q$ : Wie steht es mit der Beantwortung all der Fragen?" how stands it with the answering all the questions 'What about the answers to all the questions?'

A: Du weißt doch, ... you know PRT 'Well, you know ... 
a. dass mindestens einige Schüler fast alle Fragen that at-least some pupils almost all questions beantworten konnten

answer could 'that at least some pupils could answer almost all the questions'

b. dass [mindestens einige Fragen $]_{i}$ fast alle Schüler $e_{i}$ beantworten konnten $\exists \forall, \forall \exists$ 'that almost all pupils could answer at least some of the questions'

In 23a the only unforced reading is the scoping that corresponds to the overt order. In $23 \mathrm{~b}$ two readings are available: one corresponds to the surface linear order, the other to the base order. This is in accordance with our assumption that $23 \mathrm{a}$ is the base order and $23 \mathrm{~b}$ the scrambled order, resulting in a chain.

Let us now apply this diagnostic to the base order patterns as determined above in order to check the results and complete the coverage. Consider the examples in 24.

(24) a. dass einige Linguisten fast alle Balladen interessierten $\quad \exists \forall$ that some linguists almost all ballads interested 'that some linguists were interested in almost all ballads'

b. dass [einige Balladen] $]_{\mathrm{i}}$ fast alle Linguisten $\mathrm{e}_{\mathrm{i}}$ interessierten $\exists \forall, \forall \exists$ 'that almost all linguists were interested in some ballads'

The verb interessieren projects the argument structure EXP < THEME/CAUSE into the base order with the result that ACC precedes NOM. ${ }^{20}$ We therefore expect $24 \mathrm{~b}$ but not $24 \mathrm{a}$ to give rise to two readings.

\footnotetext{
${ }^{20}$ The reason for the remarkable ranking property is the fact that for this class of verbs, cause of emotion and target of emotion coincide. In a decomposed structure this would read: [ $\mathrm{x}$ causes [y be in a specific mental state toward $\mathrm{z}$ ]]. One argument slot is associated with two variables in the semantic form. Subject selection picks the argument associated with the highest occurrence. Ranking of arguments, however, seems to be determined bottom up, that is, the lowest occurrence determines the lowest rank. Usually, subject selection and ranking pick the same argument. Only with verbs that involve two variables for one argument in the semantic form in the A-structure may a discrepancy arise.
} 
This expectation comes true. Analogous considerations apply to the other verb classes, as the examples in 25 show.

(25) a. dass er einen Kandidaten fast allen Tests unterzogen hat $\exists \forall$ that he one candidate almost all tests subjected has 'that he subjected one candidate to almost all tests'

b. dass er [einem Test] $]_{\mathrm{i}}$ fast alle Kandidaten $\mathrm{e}_{\mathrm{i}}$ unterzogen hat $\exists \forall, \forall \exists$ 'that he subjected almost all candidates to one test'

As expected, 25a, with the base order ACC > DAT, yields only one reading, whereas $25 \mathrm{~b}$ gives rise to two readings. The converse pattern is characteristic of verbs with the base order DAT $>$ ACC, as 26 shows.

(26) a. dass er zwei Kandidaten fast alle Fragen stellte $\quad \exists \forall$ that he two candidates almost all questions put 'that he asked two candidates almost all questions'

b. dass er [zwei Fragen] $]_{\mathrm{i}}$ fast allen Kandidaten $\mathrm{e}_{\mathrm{i}}$ stellte $\quad \exists \forall, \forall \exists$ 'that he asked almost all candidates two questions'

In both cases, therefore, the scrambled order and only the scrambled order-DAT $>$ ACC in one case and ACC $>$ DAT in the other Vclass-results in two readings.

We may conclude that the data reviewed in sections 3.2.1 and 3.2.2 are prima facie evidence for the existence of verb classes with different base orders. Furthermore, these data allow us to distinguish between an argumental base order and a derived order. $^{21}$

\section{Which Elements Scramble?}

We argued above that only elements selected by the verbal head may scramble, the reason being that only these elements are mapped into syntactic structure as an effect of their ranking order in the lexical entry. This syntactic order is their base order. Scrambling produces a chain with the trace in the foot position and the scrambled element as the head of the

21 As already mentioned (notes 9 and 15), there is additional, independent comparative evidence for the claim that there are variant base orders that reflect argument structure hierarchies triggered by the conceptual organization at the lexical interface. In Icelandic, a language that does not allow scrambling, the variant orders can be read off the surface structure order (see Kress 1992, Yip, Maling, and Jackendoff 1987). 
chain. Consequently, free (that is, nonselected) adverbials in alternative positions cannot be said to scramble (see section 2 above). They are generated in their scope position. This also holds for free adverbials within the MAC (manner adverbials, for instance).

But not all selected elements scramble. Arguments are the primary candidates for scrambling. They may scramble, regardless of the category (as already mentioned, we do not discuss pronouns), namely as a DP (27a), ${ }^{22}$ as a PP (27b), as an infinitival construction (27c), or marginally as a finite $\mathrm{CP}(27 \mathrm{~d}){ }^{23}$ They therefore may move to a higher position within the (extended) VP, leaving a trace in the base position, as shown in 27.

(27) a. dass heute $[\text { dem Peter }]_{i}$ jemand $e_{i}$ auf die Zehen trat, that today the Peter somebody on the toes stepped ist deutlich is obvious 'that somebody stepped on Peter's toes today is obvious'

b. dass dort jetzt [auf Peter $]_{\mathrm{i}}$ jemand $\mathrm{e}_{\mathrm{i}}$ wartet that there now for Peter someone waits 'that someone is waiting for Peter there now'

c. dass doch [diese Tür aufzubrechen] $]_{i}$ keiner je $e_{i}$ versucht hat that PRT this door to-break-open nobody ever tried has 'that nobody ever tried to break down this door'

d. ?weil ja heutzutage [dass die Erde rund ist $]_{i}$ niemand $e_{i}$ because PRT nowadays that the earth round is nobody ernsthaft bezweifelt seriously doubts 'because nobody seriously doubts nowadays that the earth is round'

Note that we have chosen examples with the scrambled argument to the left of the subject but to the right of modal particles or temporal

${ }^{22}$ There are some restrictions with respect to genitive objects, however (cf. Rosengren 1993). Since this is of no relevance in the present discussion, we do not discuss it further.

${ }^{23}$ Nonextraposed finite argument clauses are marginal (but not ungrammatical) in both positions, that is, in the position of the head and in the position of the foot of the chain. Hence the question mark in $27 \mathrm{~d}$. 
adverbials in order to make sure that the chain is within the (extended) VP.

Let us now turn to selected nonargumental constituents and ask whether they may scramble. We discuss selected predicate-related adverbials (such as manner adverbials) and selected event-related adverbials (local adverbials, for example).

Generally, an adverbial is licensed if it can be semantically integrated in its position. The semantic wellformedness condition is a type-matching condition. The consequence is that in principle more than one position may be a possible position for linking a given adverbial. ${ }^{24}$ Let us first look at examples in 28a,b with the manner adverbial freundlich '(in a) friendly (way)'.

(28) a. dass man ja (die) Männer nicht freundlich behandelt hatte that one PRT the men not friendly treated had 'that (the) men had not been treated friendly'

b. *dass man ja freundlich $_{\mathrm{i}}(\mathrm{die})$ Männer nicht $\mathrm{e}_{\mathrm{i}}$ behandelt hatte that one PRT friendly the men not treated had

c. Freundlich $h_{\mathrm{i}}$ hat man (die) Männer nicht $\mathrm{e}_{\mathrm{i}}$ behandelt friendly has one the men not treated

As the contrasts in 28 demonstrate, a manner adverbial (28a vs. 28b) does not scramble (but it may be $\mathrm{A}^{\prime}$-moved, that is, topicalized, as in 28c). ${ }^{25}$ But why does it not scramble? The answer seems to be this. The manner adverbial would have to be semantically linked in its scrambled surface position, that is, as a modifier of the V-projection and not of the $\mathrm{V}^{0}$, whose complement it is. ${ }^{26}$ The essential difference between adverb

${ }^{24}$ See Frey and Pittner 1998: 528, for a detailed discussion of linking domains. In principle, we agree with them, but we do not accept scrambling of free adverbials, but take them to be generated in their alternative surface positions.

25 One reviewer asked whether there is "any way to tell whether the ungrammaticality in $28 \mathrm{~b}$ results from the failure of the definite NP to scramble, rather than resulting from scrambling the adverb." In the examples in the present version, we give a definite and an indefinite DP. The unacceptability effect is independent. Since neither the definite nor the indefinite DP has to scramble, the adverbial is to be blamed for unacceptability.

${ }^{26}$ In English a reflex of this condition is the ungrammaticality of selected manner adverbials in the preverbal position.

(i) *They (had) badly treated him.

(ii) They (had) treated him badly. 
licensing and argument licensing is that arguments are licensed by two conditions, namely, by morphosyntactic identification and by thematic licensing. Scrambling dissociates these conditions. If an adverb is selected by a head, only its semantic requirement is specified, not its categorical identification features. Unlike arguments, adverbials are not selected by syntactic category but only by content.

The following German example (29) with a selected local adverbial (in London) shows that selected adverbials may occur in alternative positions. Local adverbials are event-related, that is, their domain is the VP. So the VP-adjoined position is a possible licensing position for local adverbials (but not for manner adverbials, whose semantic domain is smaller; see Frey and Pittner 1998). Given that both the base position and the target position must meet the same licensing requirements, scrambling of local adverbials is possible, but scrambling of manner adverbials is not.

(29) a. dass seine Eltern in London wohnen.

WF that his parents in London live

b. dass in London seine Eltern wohnen.

$\mathrm{NF}$

As shown in 30 , directional adverbials do not scramble. This is expected since they behave in principle like result predicates $(31)^{27}$ and form a complex predicate with the verb (see Neeleman 1995, Haider 1997d), much like particles and verbs, for example hinein 'into' and heraus 'out of'. The licensing conditions for both types of predicates are analogous to selected manner adverbials. ${ }^{28}$

(30) *dass er ja [unter den Papierkorb $]_{\mathrm{i}}$ alles $\mathrm{e}_{\mathrm{i}} \quad$ legte that he PRT under the wastebasket everything put 'that he put everything under the wastebasket'

(iii) They (had) badly fixed it.

The selected adverbial must be postverbal, since the canonical selection direction for English as $\mathrm{VO}$ is progressive.

${ }^{27}$ This is due to their indicating the position of an item that results from the process it is involved in. Resultative predicates are discussed in some detail in Koch and Rosengren 1995 and Winkler 1997.

${ }^{28}$ Again, we use a modal particle to indicate that it is not clause-internal topicalization we are observing here. 
(31) *dass er ja [in so viele Stücke $]_{\mathrm{i}}$ alles $_{\mathrm{i}} \quad$ zerriss that he PRT in so many pieces everything tore-up 'that he tore up everything into so many pieces'

Selected time adverbials do not scramble. ${ }^{29}$ Note, however, that selected adverbials may be topicalized. This shows that they are able to enter chain relations. To sum up: argumental DPs, PPs and CPs scramble. Predicates of any kind do not scramble.

\section{How the Theory Accounts for the Facts.}

In this section we describe, discuss, and test some of the expected consequences of the assumption that scrambling is overt chain formation within the (extended) VP, permitted where grammar does not forbid it. From this assumption follows that scrambling:

i. is strictly clause-bound;

ii. may not target functional Spec positions;

iii. is non-string-vacuous;

iv. can target any visible position within the (extended) VP;

v. is syntactically optional;

vi. can apply to more than one phrase;

vii. extends the binding domain of scrambled elements and gives rise to scope ambiguities.

\subsection{Scrambling is Strictly Clause-Bound.}

Scrambling is strictly limited to the domain of the verbal head, since only in this domain the scrambled constituent can be licensed. This claim is uncontroversial both for scrambling out of finite as well as out of infinitival clauses. The sentences in 32 demonstrate the prohibition against scrambling out of the domain of the verbal head.

\footnotetext{
${ }^{29}$ They are restricted to a few verbs. We regard them as predicate-related in the same way as are directionals.

(i) *Die Vorlesung wird [zwei Stunden $]_{i}$ vermutlich heute $e_{i}$ dauern.

the lecture will two hours probably today last

'The lecture will probably last two hours today.'
} 
(32) a. *dass sie ja viel $_{\mathrm{i}}$ nicht erwartet hat [dass man dafür $\mathrm{e}_{\mathrm{i}}$ that she PRT much not expected has that one for-it bezahlen müsse]

pay would-have-to 'that she did not expect that one would have to pay much for it'

b. *dass sie ja viel $_{\mathrm{i}}$ nicht erwartet hat, dafür $\mathrm{e}_{\mathrm{i}}$ bezahlen $\mathrm{zu}$ that she PRT much not expected has for-it pay to müssen have-to

c. Viel hat sie nicht erwartet [dafür zahlen zu müssen / dass sie dafür zahlen müsse]

32a,b are unacceptable instances of nonlocal scrambling. Fronting the scrambled element to the position immediately after the matrix $\mathrm{C}^{0}$ would not improve the result. 32c involves topicalization, that is, $\mathrm{A}^{\prime}$-movement, and is entirely grammatical.

As for the upper boundary of scrambling, note that scrambling is possible within a topicalized $\mathrm{V}$-projection. This indicates that the domain of scrambling is the VP. Below we show that it is only the VP and not any higher functional domain. $33 \mathrm{~b}$ is a scrambled variant of $33 \mathrm{a}$ (see Haider 1997a:66).

(33) a. [Dem $Z_{w e i t e n}{ }_{\mathrm{DAT}}$ den Ersten $_{\mathrm{ACC}}$ anvertraut] hat der Dritte. the second-one the first-one entrusted has the third-one 'To the second one, the third one entrusted the first one.'

b. [[Den Ersten $]_{\mathrm{i} / \mathrm{ACC}}$ dem Zweiten $\mathrm{DAT}_{\mathrm{D}} \mathrm{e}_{\mathrm{i}}$ anvertraut] hat der Dritte. the first-one the second-one entrusted has the third-one

These examples show that scrambling may take place within the VP. Based also on the evidence (to be discussed in section 5.2.1) against assigning scrambled elements to functional Spec positions and the evidence that adjunctions to higher functional projections create opaque domains (opacity arguments), the conclusion will be the following: For elements selected by $\mathrm{V}^{0}$, the domain of scrambling is the $\mathrm{V}$-projection and only the V-projection. 


\subsection{Scrambling Does Not Target Functional Spec Positions.}

This negative statement rests on two claims. First, scrambled XPs do not display the properties of constituents hosted by functional Spec positions (section 5.2.1). Second, there is no independent evidence for a featuretriggered movement to an F-Spec (section 5.2.2) nor for the presence of the f-head itself. Finally, in section 5.2.3 we review and disqualify the evidence for scrambling as $\mathrm{A}^{\prime}$-movement that rests on the apparent evidence of parasitic gap constructions licensed by scrambling.

5.2.1. Evidence against Scrambled Constituents Hosted by Functional Spec Positions.

In this section we mention just two independent issues that militate against an assumption that the scrambled constituent is in a functional Spec position (for a more detailed discussion see Haider and Rosengren 1998). The particular status as A- or A'-position is of no importance in this connection, since $\mathrm{A}^{\prime}-$ as well as A-Specs behave in the same way with regard to the following properties. First, scrambled XPs remain transparent for extraction (contra Diesing 1992 and Müller 1998), and this is generally not the case for functional Specs. Second, neither a multiple F-Spec analysis nor a multiple F-projection analysis can capture the freedom of scrambling orders in German.

Let us start with the argument from extraction patterns, namely transparency for extraction. In a language with easily identifiable Spec positions, English, for example, XPs in Specs are opaque for extractions. Consider 34a,b.

(34) a. Who did he sell a picture of ?

b. *Who has [a picture of $\mathrm{e}_{\mathrm{i}}$ ] been sold? (opacity of Spec,IP; "subject condition")

XPs, topicalized to positions between Spec,IP and $\mathrm{C}^{0}$, are opaque as well (see $35 \mathrm{~b}$ and 36b). This indicates that this position is either a Spec position or it is a position adjoined to IP. In both cases, extraction is illicit, as the evidence suggests. ${ }^{30}$

(35) a. (that) [a picture of this painter] virtually everyone has admired

\footnotetext{
${ }^{30}$ Remember that the theoretic modeling of the opacity phrases in functional Spec positions and of phrases adjoined to functional projections was a central issue in grammatical theory for more than a decade at the end of the last century.
} 
b. ${ }^{*} \mathrm{Who}_{\mathrm{i}}$ has [a picture of $\mathrm{e}_{\mathrm{i}}$ ] virtually everyone admired?

(36) a. (that) [with him] I should talk at once

b. ${ }^{*} \mathrm{Who}_{\mathrm{i}}$ should [with $\mathrm{e}_{\mathrm{i}}$ ] I talk at once?

The ungrammaticality of the b-examples cannot be attributed to an adjacency requirement for $\mathrm{V}$ and the preposition. ${ }^{31}$ Crosslinguistic evidence can be found, for instance, in Danish (cf. Vikner 1994:248) showing that prepositions can be stranded at distance to the verb.

In German, scrambled infinitival clauses are not opaque domains for extraction. ${ }^{32}$ Neither scrambling (37b) nor extraposition (37c) has an effect on extractability.

(37) a. dass schon mal jemand [ihn damit zu überzeugen] that already PRT someone him with-this to convince versucht hat

tried has

'that someone already tried to convince him with this'

b. $\mathrm{Wen}_{\mathrm{i}}$ hat (denn) $\left[\mathrm{e}_{\mathrm{i}} \text { damit zu überzeugen }\right]_{\mathrm{j}}$ jemand $\mathrm{e}_{\mathrm{j}}$ who has PRT with-that to convince] someone versucht?

tried

'Who did someone try to convince with this?'

${ }^{31}$ Examples such as Who was taken advantage of? or Who did you give this book to? show clearly that the verb and the preposition are not adjacent heads because in both examples the preposition is not adjacent to the verbal head.

${ }^{32}$ Extraction out of scrambled DPs is not blocked either. In the following examples, the PP has been extracted out of a scrambled DP. (The second example is adapted from Fanselow 1993.)

(i) $[\text { Von Chomsky }]_{j}$ hat ja mindestens [ein Buch $\left.e_{j}\right]_{i}$ fast jeder $e_{i}$ gelesen. by Chomsky has PRT at-least one book nearly everyone read 'Almost everyone has read at least one book by Chomsky.'

(ii) [Über Logik $]_{\mathrm{j}}$ sind [alle Bücher $\left.\mathrm{e}_{\mathrm{j}}\right]_{\mathrm{i}}$ leider $\mathrm{e}_{\mathrm{i}}$ ausgeliehen. about logic are all books unfortunately lent-out 'Unfortunately, all books about logic are checked out.'

We will, of course, only find extracted PPs, since there are no accusative and dative adjuncts within the DP. 
c. Wen ${ }_{\mathrm{i}}$ hat (denn) jemand versucht $\left[\mathrm{e}_{\mathrm{i}}\right.$ damit zu überzeugen]? who has PRT someone tried with-that to convince

Diesing's (1992:32-33) claim that scrambling creates opaque domains is based on inadequately chosen data. She adduces "was-für split" constructions as the main body of evidence. The contrast in 38a,b is interpreted as the result of an opacity-effect incurred by scrambling.

(38) a. $\mathrm{Was}_{\mathrm{i}}$ erzählte denn jeder von euch [ $\mathrm{e}_{\mathrm{i}}$ für Witze]? what told PRT everyone of you for jokes 'What kind of jokes did everyone of you tell?'

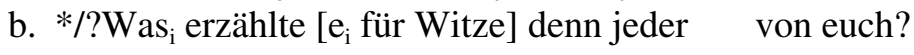
what told for jokes PRT everyone of you?

c. ?/* $\mathrm{Was}_{\mathrm{i}}$ missglückten [e $\mathrm{e}_{\mathrm{i}}$ für Witze]? what failed for jokes

'What kind of jokes failed?'

The degraded acceptability of $38 \mathrm{~b}$, which we do not regard as ungrammatical, cannot be the result of scrambling. The effect is independent of scrambling, as $38 \mathrm{c}$ illustrates. $38 \mathrm{c}$ is deviant despite the fact that the subject is the subject of an unaccusative verb and may remain in its base position. We conclude that $38 \mathrm{~b}$ is deviant for some reason other than scrambling. The following examples run counter to Diesing's premise. ${ }^{33}$

(39) a. Was $\mathrm{Wat}_{\mathrm{i}}$ hann jeder von euch den jeweils anderen what has PRT each of you the respective others [ $\mathrm{e}_{\mathrm{i}}$ für Witze erzählt]?

for jokes told 'What kind of jokes did each of you tell the others?'

b. Was ${ }_{\mathrm{j}}$ hat denn jeder von euch $\left[\mathrm{e}_{\mathrm{j}} \text { für Witze }\right]_{\mathrm{i}}$ den jeweils what has PRT each of you for jokes the respective andern $\mathrm{e}_{\mathrm{i}}$ erzählt?

others told

c. (?) $\mathrm{Was}_{\mathrm{i}}$ hat denn $\left[\mathrm{e}_{\mathrm{i}} \text { für Witze }\right]_{\mathrm{j}}$ so jeder von euch what has PRT for jokes PRT each of you gestern $e_{j}$ erzählt? yesterday told

\footnotetext{
${ }^{33}$ Thanks to Marga Reis for mentioning these examples.
} 
One of the two orders of the objects in $39 \mathrm{a}, \mathrm{b}$ is the result of scrambling and the other is the base order. In our theoretical framework, it must be $39 \mathrm{~b}$. Extraction is perfect in both orders. Even extraction out of a presubject position $(39 \mathrm{c})$ is acceptable, though somewhat marked. In sum, the data Diesing has adduced as evidence for the islandhood of scrambled constituents are not directly relevant to the issue.

The second issue mentioned at the beginning of this section is the complete permutation range of scrambling in German (see example 1). This calls for an adequate structural solution. Cascading functional projections are ordered and would be the outcome of scrambling-if scrambling were to be explained as cascading functional projections. Scrambling would map one particular order onto another particular order. From this perspective, scrambling would not be equivalent to the free (VP-internal) rearrangement of case-marked arguments. It should rather behave like Object Shift, which is not the case (cf. Collins and Thráinsson 1996:410; also section 5.2.2). Accumulating scrambled items in a multiple-Spec projection would not be adequate either since scrambled items may be separated by intervening adverbials and modal particles. They do not come in packages.

5.2.2. Evidence against the assumption that scrambling is syntactically triggered.

In this section we argue against trigger accounts based on morphosyntactic feature checking, as well as all accounts that appeal to some kind of interpretation-driven movement.

The basic problem with all these accounts is the following. Either they beg the question and/or they are too strong or too weak. It begs the question if a scrambling feature is postulated merely for the purpose of triggering scrambling. ${ }^{34}$ An example of too weak an account is one that categorically restricts the features to DP-type case features (examples include van den Wyngaerd 1989, Mahajan 1994, Miyagawa 1997, for IPadjunction). Various empirical considerations, such as the existence of VP-internal scrambling (example 33) and the lack of opacity of scrambled phrases, notably of scrambled infinitival clauses (example 37),

${ }^{34}$ No insight is gained if one postulates a feature [+scr] to trigger scrambling (see Sauerland 1999) and to relate the optionality of scrambling with the optional presence of this feature. 
militate against scrambling being triggered by the need for DPs to be case-licensed in specific case positions (that is, functional Spec positions). More generally, DP feature-triggered scrambling does not cover non-DP scrambling. As demonstrated in section 4, CPs-both finite as well as infinitival ones-and PPs may scramble. Thus casedriven movement (that is, movement into F-Specs of case-checking heads) is doomed to fail from the beginning. At the same time, these accounts are too strong if they entail that scrambling is obligatory (in other words, that features must be checked); scrambling is, of course, not obligatory.

Interpretation-driven movement cannot be successfully invoked either since the reading associated with the scrambled constituent is available in the base order too. Shifting optionality to the optional presence of a trigger is not a viable avenue. For more general aspects of interpretation-driven movement, see Adger 1994. Below we briefly discuss two meaning-based triggering hypotheses.

De Hoop (1992), who characterizes scrambling as optional Achaining, maintains that "strong case positions" are associated with "strong readings," and that only "strong DPs" may scramble. ${ }^{35}$ Her generalization is the following: If a DP is scrambled, it can only be strong. But this generalization fails in both directions. Unscrambled DPs may have a strong reading in the base position, and scrambled DPs may keep their weak reading (see also Ruys 2001). ${ }^{36}$ Therefore, if there is no clear-cut difference between the positions of [ \pm strong] DPs, the positional account of strength is undermined.

The fact that weak readings are not found in scrambled positions can be derived in a more straightforward manner. It suffices to assume a simple interface condition: a semantic domain, namely the domain of existential closure ( $=$ the source of weak readings) is correlated with a syntactic domain, namely the MAC, that is, the minimal complete Vprojection (in terms of argument discharge). Diesing (1992) equates this domain with the complete VP. This is adequate for VO languages since in head-initial V-projections the VP and the MAC are congruent. The

\footnotetext{
${ }^{35}$ Note once more that not only DPs scramble.

${ }^{36}$ Here is a Dutch example from Ruys 2001:51: ... dat elke arts wel een of andere ziekte mestal met penicilline behandelde 'that every doctor PRT one or (an)other disease usually with penicillin treated'. The indefinite precedes a frequency adverb (in its alleged scrambled position), but nevertheless keeps its existentially bound reading. This is true for German.
} 
need to distinguish between the MAC and the extended VP becomes obvious only in OV languages.

If the minimal V-projection (that is, the MAC) is the domain of existential closure, a DP scrambled out of this domain will lose the existential reading. Hence it will have to receive an interpretation other than by existential closure, namely a generic or specific one. This is what de Hoop calls a strong reading. The German examples in 40 illustrate this point. 40a allows an existentially bound reading for the bare plural object that is not available if the bare plural is scrambled in $40 \mathrm{~b}$.

(40) a. dass ja Max Primaballerinas bewundert that PRT Max prima ballerinas admires 'that Max admires prima ballerinas'

b. dass ja Primaballerinas Max bewundert that PRT prima ballerinas Max admires

c. dass ein Linguist Primaballerinas bewunderte that a linguist prima ballerinas admired

c. dass ja jemand \{an Primaballerinas Rosen / Rosen an that PRT someone to prima ballerinas roses roses to Primaballerinas \} verschenkte prima ballerinas gave 'that someone gave roses to prima ballerinas'

e. dass ja an Primaballerinas jemand Rosen verschenkte that PRT to prima ballerinas someone roses gave

However, 40a can receive the same interpretation as 40b, namely, If someone is a prima ballerina, then Max admires this person. $40 \mathrm{c}$ is meant to remove any doubt that the indefinite in 40a has moved at all, after movement of the definite DP. In 40c the indefinite subject DP can receive an existential reading and the object can still get a generic (or a specific) reading: If someone was a prima ballerina, then there was a linguist who admired her.

The fact that there is a difference between $40 \mathrm{a}$ and $40 \mathrm{~b}$ - the existential interpretation is lost in the scrambled order $40 \mathrm{~b}$ - is irrelevant in this context of argumentation. What would be essential for a "triggering" scenario of the kind de Hoop proposes is not a loss, but an exclusive gain. The loss of an interpretation is independent of any triggering device. It is simply a domain effect: scrambling that leaves the 
MAC, that is, the domain of existential closure. From this it follows that scrambling within the MAC preserves the existential reading, while scrambling out of the MAC "destroys" it. This is illustrated by the contrast between 40d and 40e. The indefinite in the goal PP is within the MAC in 40d, thus it can get an existential reading, or alternatively also a specific reading. In 40e, however, the indefinite PP is not in the MAC, and so it gets a "strong" reading. We conclude that the differences in readings are not the cause of scrambling but an effect.

Delfitto and Corver (1997) suggest positing a feature with content, namely the feature "familiarity," which is not categorically restricted. This feature is supposed to trigger scrambling. If an item is marked with [+familiar], it must scramble. The authors do not tell us precisely where the F-head is located in the clause, or how multiple scrambled nonadjacent elements are to be handled. As in the case of strong readings, the reading claimed for scrambled constituents is not exclusive to scrambling. The very same reading is possible in the base order, as the examples in 41 demonstrate.

(41) a. In diesem Sack sind zwei rote Kugeln und eine weiße. in this bag are two red balls and one white-one 'In this bag there are two red balls and one white one.'

b. Wenn jemand die weiße Kugel zieht, hat er gewonnen. if someone the white ball draws has he won 'If someone draws the white ball he has won.'

c. ?Wenn die weiße Kugel jemand zieht, hat er gewonnen. if the white ball someone draws has he won

The existence of a unique object that is a white ball is familiar in the context given in 41a. Nevertheless, scrambling is not only not obligatory, it is in fact not even adequate, as the contrast between $41 \mathrm{~b}$ and $41 \mathrm{c}$ shows. The definite DP that denotes a familiar discourse participant, namely the white ball, nevertheless stays behind the indefinite subject, although scrambling would produce a perfectly grammatical result. Eventually, all other objections against scrambling as targeting functional Specs apply to this account as well. Thus, this type of solution is also falsified by empirical evidence.

Finally, if scrambling were triggered, it ought to be found to operate in at least some other Germanic languages as well, for instance, in Icelandic, with its rich morphological system of case-marking and a movement phenomenon called Object Shift. This is not what we find, 
however (see Collins and Thráinsson 1996:410). Although a pre-VP position is accessible for Object Shift, this movement process conserves the base order, both for subject-object order $(42 \mathrm{a}, \mathrm{b})$ as well as for double object constructions. In German, both orders are available.

(42) a. Í gær las Jón bækurnar ekki. yesterday read John books-the not 'Yesterday John did not read the books.'

b. *Ígær las bækurnar ${ }_{\mathrm{i}}$ Jón ekki $\mathrm{e}_{\mathrm{i}}$. yesterday read books-the John not

c. Gestern las Hans die Bücher nicht. (= 42a) yesterday read Hans the books not

d. Gestern las die Bücher Hans nicht. (=42b) yesterday read the books Hans not

If there were a syntactic trigger for scrambling in German, the difference between the availability of scrambling in German and the lack of scrambling in Icelandic would have to be reduced to an accidental property: it "just so happens" that the relevant feature is strong in German but weak in Icelandic. The difference is not accidental, however. It is a difference that relates directly to the OV vs. VO difference, as we emphasize below. Thus, arbitrary assignment of strong/weak values is but a technical option, but the relevant generalization would be missed.

At this point, let us summarize general facts about triggering and optionality. Scrambling is not syntactically triggered, as, for instance, NP-movement in the English passive is. There is no context in which a phrase must be scrambled. We do not contest, however, that scrambling does have effects at the semantics/pragmatics interface; we simply deny the need and justification to elevate these properties to the status of a syntactic triggering feature. We take the interpretation effects to be epiphenomena of scrambling, and not the cause. If there is optionality at the level of the syntax module, this does not mean that the resulting variants are in free variation for all other modules of grammar. ${ }^{37}$ Scrambling is truly optional (see also Saito and Fukui 1998) in syntactic

${ }^{37}$ German provides evidence for this case too. For a large class of verbs in German, the clause union variant of sentential infinitives is in free variation with the sentential complement variant, and there is no effect whatsoever on semantic or pragmatic interpretation (see Haider 2003). 
terms, but of course the output of the syntax module interacts with other modules of the grammar (especially at the semantic and pragmatic and the PF interface). The effects of the interface, however, should not be misinterpreted as syntactic triggers (contrary to Zubizarreta 1998). Neeleman and Reinhart (1997) make this point-economy of stress strengthening with focus assignment-particularly clear for the alternative orders of objects with respect to adverbials in Dutch; the phenomenon known as "Dutch scrambling" under Neeleman and Reinharts's analysis involves base order alternation.

\subsubsection{Parasitic Gaps as Evidence for A'-specs? No!}

The phenomenon of parasitic gaps has been considered the cardinal evidence for A'-dependencies. For German, however, as has been pointed out by Webelhuth (1992:410-411; see also Grewendorf and Sabel 1999), its impact is more confusing than revealing. Consider the examples in 43.

(43) a. ?Er hat jeden ${ }_{i}^{\mathrm{i}}$ Gast [ohne $\mathrm{pg}_{\mathrm{i}}$ anzuschauen] seinem ${ }^{\mathrm{i}}$ Nachbarn $\mathrm{e}_{\mathrm{i}}$ he has every guest without to-look-at his neighbor vorgestellt. introduced

'He introduced every guest, without looking at him, to his neighbor.'

c. ?Er hat die Gäste ${ }_{i}^{i}$ [ohne $\operatorname{pg}_{i}$ anzuschauen] einander ${ }^{i} e_{i}$ he has the guests without to-look-at each-other vorgestellt. introduced

If 43 is a parasitic gap (pg) construction, its pattern is inconsistent with standard assumptions. On the one hand, a parasitic gap needs an A'chain for licensing. On the other hand, $\mathrm{A}^{\prime}$-antecedents cannot bind anaphors and would trigger weak crossover violations. In 43a the scrambled quantified DP binds a pronoun without a weak crossover effect, and in $43 \mathrm{~b}$ the scrambled object binds an anaphor. These properties are associated with A-positions, however. Since under standard assumptions a position cannot simultaneously be treated as A and $\mathrm{A}^{\prime}$, there are either two movement steps involved (see Mahajan 1994), or the dichotomy must be relaxed (compare Deprez 1994), or the data must be reevaluated for their validity. We advocate the latter option.

At least for German, identifying constructions such as 43 as parasitic gap constructions is of questionable validity. To begin with, the gaps in 
adverbial infinitival clauses do not have the properties of parasitic gaps in English, as the comparison between $44 \mathrm{a}-\mathrm{c}$ and $45 \mathrm{a}-\mathrm{c}$ illustrates. The typical cases of English (44d) are severely deviant in German (45d). Parasitic gap constructions with the gap in a finite clause are ungrammatical in German. Only infinitival adjuncts (45a-c) seem at first glance to display a parasitic gap-like behavior. The four examples in 44 are from Postal 1993:737, 746, 736, 748, respectively.

(44) a. *Where did Elaine work $e_{i}$ without ever living $e_{i}$ ?

b. *What he became $\mathrm{e}_{\mathrm{i}}$ without wanting to become $\mathrm{e}_{\mathrm{i}}$ was a traitor.

c. *This is a topic about which he should think $\mathrm{e}_{\mathrm{i}}$ before talking $\mathrm{e}_{\mathrm{i}}$.

d. ?Which disease did everyone who caught $\mathrm{e}_{\mathrm{i}}$ want Dr. Jones to study $\mathrm{e}_{\mathrm{i}}$.

(45) a. Wo hat Elaine, anstatt mit dir [-] zu wohnen, ihr Büro where has Elaine instead-of with you to live her office eingerichtet? (= 44a)

set-up

'Where did Elaine set up her office instead of living there together with you?'

b. Was er wurde, ohne eigentlich [-] werden zu wollen, war what he became without actually become to want was ein Syntaktiker. (= 44b)

a syntactician

'What he became without really wanting to do was become a syntactician.'

c. Das ist ein Thema, über das er, anstatt [-] zu schwätzen, that is a topic about which he instead-of to chat nachdenken sollte. $(=44 \mathrm{c})$ think-over should 'This is a topic he should think about instead of chatting.'

d. *Welches Haus wollte jeder, dem er $e_{i}$ zeigte, $e_{i}$ which house wanted everyone whom he showed sofort kaufen?

at-once buy

Furthermore, the same type of construction is found with elements that do not scramble easily. Wh-elements in situ license the alleged 
parasitic gaps, both in the function of a $w h$-interrogative (46a) as well as in the function of a $w h$-indefinite (46b).

(46) a. Wer hat seinem Nachbarn wen [ohne [-] anzuschauen] who has his neighbor whom without to-look-at vorgestellt? introduced 'Who introduced somebody/whom to his neighbor without looking at (him)?'

b. Er hat seinem Nachbarn wen [ohne [-] anzuschauen] he has his neighbor whom without to-look-at vorgestellt. 'He introduced somebody to his neighbor without looking at (him)'.

Fanselow (1993) adduces additional evidence against a parasitic gap analysis for structures like $45 \mathrm{a}-\mathrm{c}$. He notes parallels between this construction and conjunction reduction and concludes that ohne 'without' and anstatt 'instead of' function syntactically like coordinating heads. The alleged parasitic gaps are in fact the result of coordination ellipsis (compare 47b) and not the result of the parasitic gap-type variable binding mechanism. Viewed from this perspective, it is no longer surprising that the alleged parasitic gap construction may contain multiple gaps (47a), which is ruled out for parasitic gaps and characteristic of ellipsis constructions (47b).

(47) a. dass er eine $\operatorname{Frau}_{\mathrm{i}}$ einem $\mathrm{Mann}_{\mathrm{j}}$ [anstatt $\mathrm{e}_{\mathrm{i}} \mathrm{e}_{\mathrm{j}}$ vorzuziehen] that he a woman a man instead-of to-prefer unterordnen wollte subordinate wanted 'that he wanted to subordinate a woman to a man instead of preferring her over him'

b. dass er eine Frau einem Mann zuerst unterordnete und dann that he a woman a man at-first subordinated and then [- vorzog] preferred 'that he first subordinated a woman to a man and then preferred her to him' 
Once it is realized that elliptic infinitivals are not cases of parasitic gap constructions in German (and equally in Dutch), the puzzling conflict between A- and A'-properties disappears, as does the support for an $\mathrm{A}^{\prime}$ movement analysis of scrambling in German: scrambling does not feed parasitic gaps, therefore parasitic gaps are not evidence for the claim that scrambling chains are $\mathrm{A}^{\prime}$-chains.

These data have an impact on a Spec-F analysis of scrambling positions, as well. If scrambling targeted F-positions, regular parasitic gap constructions would be unavoidable. Bavarian, a German dialect, allows parasitic gaps, but—as the theory predicts—only if the licensing phrase is moved to an A'-position; compare 48.

(48) $\mathrm{Die}_{\mathrm{i}}$, wenn ich pg seh, grüß ich $\mathrm{e}_{\mathrm{i}}$.

her if I see greet I

'If I see her, I'll greet her.'

We therefore conclude that scrambling does not target a functional Spec position. This is what is predicted by our account of scrambling as being the VP-internal chain formation of selected XPs. ${ }^{38}$

\subsection{Scrambling is Never String-Vacuous.}

We maintain that scrambling cannot be string-vacuous. There is always overt material between the scrambled element and its trace position. The sequence in 49 a could be captured by the base structure in $49 \mathrm{~b}$ or by a string vacuous scrambling structure, as in $49 \mathrm{c}$.

(49) a. ... DP $\mathrm{DP}_{\mathrm{i}} \mathrm{DP}^{0}$

b. $\left[\ldots\left[\mathrm{DP}_{\mathrm{i}}\left[\mathrm{DP}_{\mathrm{j}} \mathrm{V}^{0}\right]\right]\right]$

c. $\left[\ldots\left[\mathrm{DP}_{\mathrm{i}}\left[\mathrm{DP} \mathrm{P}_{\mathrm{j}}\left[\mathrm{e}_{\mathrm{i}} \mathrm{e}_{\mathrm{j}} \mathrm{V}^{0}\right]\right]\right]\right]$

d. $\left[\ldots\left[\mathrm{DP}_{\mathrm{j}}\left[\mathrm{DP} \mathrm{e}_{\mathrm{i}} \mathrm{e}_{\mathrm{j}} \mathrm{V}^{0}\right]\right]\right]$

The structure in $49 \mathrm{~b}$ is the minimal convergent structure for $49 \mathrm{a}$. The analysis in $49 \mathrm{c}$ is ruled out by economy of projection. ${ }^{39}$ The only possible

\footnotetext{
${ }^{38}$ For arguments against the evidence for $\mathrm{A}^{\prime}$-dependencies from parasitic gaps in Dutch, see Neeleman 1994, section 2.3.

39 See Haider 1997c, which invokes the principle: Project the minimal convergent structure. Its corollary: Do not project a trace if the potential
} 
scrambling structure is $49 \mathrm{~d}$, that is, movement of one DP across another, the result being an overt change in the order of arguments that differs from the base order in 49a.

Another indicator for a scrambled position can be intervening material in positions higher than the MAC. An argument that precedes this material must be in a scrambling position. In the next section we discuss possible scrambling positions in German and Dutch.

\subsection{Scrambling May Target Any Position within the VP.}

In German, any position preceding the verb in a head-final projection can be the head of a scrambling chain provided the chain is not stringvacuous (see above) and the foot of the chain is the base position of the scrambled element. Hence scrambling may be strictly MAC-internal. Evidence for this claim is yielded by scrambling within topicalized Vprojections (compare the sentences in 33) and the fact that VP-internal scrambling of indefinites does not change their existential reading (see the discussion of 40). But scrambling may also extend the VP by adjunction to the MAC. We will, in other words, not only expect scrambling past the subject (compare the tree in 5) but also past free adverbials adjoined to the VP. Focus data once more provide evidence that this assumption is correct.

In 50a the word order is basic in the sense that the arguments occur in the relative word order $\mathrm{S}>\mathrm{IO}>\mathrm{DO}$. But at the same time the subject has scrambled past the free adverbials (with no impact on the focus).$^{40} \mathrm{In}$ $50 \mathrm{~b}$ both the subject and the direct object are scrambled past the free adverbials and the focus is narrow, due to the scrambling of the DP object that in its base position would be the focus exponent (that is, the constituent carrying the nuclear accent) in a wide focus reading.

antecedent of the trace is well formed if projected in its base position. See also Fox 2000:75 on word order economy.

${ }^{40}$ In German, as in other languages, the subject tends to occur as far to the left as possible. The position to the right of the particle indicates, however, that in this case the subject is not in a functional Spec. We believe this tendency to be due to the function of the subject as an unmarked topic. We disregard this specific regularity, since it is of no concern for the present issue. 
(50) a. weil Peter vermutlich heute seiner Freundin because Peter probably today his girlfriend [das neue Haus] gezeigt hat the new house showed has 'because Peter probably showed his girlfriend the new house today'

b. weil Peter [das neue Haus] $]_{i}$ vermutlich heute seiner Freundin because Peter the new house probably today his girlfriend $\mathrm{e}_{\mathrm{i}}$ gezeigt hat NF showed has

With this in mind, let us examine some well known differences between Dutch and German. The lack of overt case in Dutch necessitates a positional system of identification; consequently, DP arguments must keep their relative order (see Neeleman and Weerman 1999:78 for Dutch). Scrambling of a DP object across the subject is ungrammatical (see 51a,b), and so is scrambling of one DP object across another one (see 52b). ${ }^{41}$ PP arguments, however, may scramble across other arguments since they are not identified by case, but by the lexical head of the PP (see 52c,d). The data in 52 are from Geerts et al. 1984:989-990.

(51) a. dat (er) iemand krakers oppakt that there someone squatters arrests 'that someone arrests squatters'

b. *dat (er) krakers i $_{\mathrm{i}}$ iemand $\mathrm{e}_{\mathrm{i}}$ oppakt that there squatters someone arrests

(52) a. Toen hebben de autoriteiten de moeder het kind teruggegeven. then have the authorities the mother the child back-given 'Then the authorities gave the child back to its mother.'

${ }^{41}$ Als een onderwerp, een lijdend voorwerp en een indirect object die substantief(groep) zijn samen voorkomen, dan is de onderlinge volgorde: onderwerp-indirect object-lijdend voorwerp (Geerts et al. 1984:989). (If a subject, an object, and an indirect object that are noun phrases appear together, then the base order is: subject—indirect object—direct object; translation my own, HH.) 
b. *Toen hebben de autoriteiten het kind $_{\mathrm{i}}$ de moeder $\mathrm{e}_{\mathrm{i}}$ then have the authorities the child the mother teruggegeven.

back-given

c. Toen hebben de autoriteiten het kind aan de moeder then have the authorities the child to the mother teruggegeven. back-given

d. Toen hebben de autoriteiten aan de moeder $_{\mathrm{i}}$ het kind $\mathrm{e}_{\mathrm{i}}$ then have the authorities to the mother the child teruggegeven.

back-given

The PP may in principle appear in any position in the VP. It can even precede the subject, as the data in 53 show.

(53) a. dat (er) niemand wat voor je vader meegebracht heeft that there no-one something for your father brought-with has 'that no one brought your father anything'

b. dat (er) voor je vader $_{\mathrm{i}}$ niemand wat $\mathrm{e}_{\mathrm{i}}$ meegebracht heeft that there for your father no-one something brought-with has

Since PP objects follow DP subjects and DP objects in the base order, it is safe to assume that $53 \mathrm{~b}$ is the result of scrambling, with a trace in the base position of the PP object to the right of the subject and the direct object.

Our definition of scrambling (see section 2) correctly identifies these contexts as possible scrambling contexts in an OV language like Dutch: DP objects cannot scramble across each other, nor across a subject, because there is no morphologically overt identification system, or, in other words, because the licensing system is structural, and not morphological.

There are some apparent exceptions, however. First, just as in German, it is possible for subjects and objects to precede free adverbials (see 54a-b), and just as in German, we take free adverbials to occur in alternative positions. ${ }^{42}$ The different readings of indefinites are interface

\footnotetext{
${ }^{42}$ We agree with Neeleman and Reinhart (1997), who argue for free attachment of adverbs in the Dutch inner field. Hence, the alternative order of arguments and adverbs is not seen as the result of movement.
} 
effects. An event-related adverbial or any higher one requires its domain to be interpreted as an event domain. If an indefinite precedes, it cannot get an existentially bound reading because this is available only within the event domain. Second, it is possible to front a nominative across an object. This happens optionally with unaccusative subjects. The examples in 54c-f are borrowed from Broekhuis 2000; see also Rosengren 2002.

(54) a. dat de politie/iemand gisteren krakers oppakte that the police/someone yesterday squatters arrested 'that the police/someone yesterday arrested squatters'

b. dat de politie/iemand krakers $_{(i)}$ gisteren $\left(\mathrm{e}_{\mathrm{i}}\right)$ oppakte that the police/someone squatters yesterday arrested

c. dat het meisje de ergste rampen $_{\mathrm{NOM}}$ overkwamen that the girl the most-terrible disasters happened 'that the most terrible disasters happened to the girl'

d. dat [de ergste rampen $\left.{ }_{\mathrm{NOM}}\right]_{\mathrm{i}}$ het meisje $\mathrm{e}_{\mathrm{i}}$ overkwamen that the most-terrible disasters the girl happened

e. dat (er) een meisje erge rampen NOM $_{\text {overkwamen }}$ that there a girl terrible disasters happened

f. dat (er) [erge rampen $\left.{ }_{\mathrm{NOM}}\right]_{\mathrm{i}}$ een meisje $\mathrm{e}_{\mathrm{i}}$ overkwamen that there terrible disasters a girl happened

In $54 \mathrm{c}$,e the word order is the base order; in $54 \mathrm{~d}$, f the nominative has moved across the indirect object. Indefinite subjects may cooccur with the expletive er, resulting in an existential reading. In 54e,f, however, the reading is existential with and without an expletive. We assume that the subject in $54 \mathrm{~d}$ has moved to a structural subject position (otherwise obligatorily filled with the expletive), and in 54f we take it to be scrambled to the VP subject position, that is, it remains within the domain of existential closure. This is the reason why the expletive may be present or not. It is only obligatory when the subject is missing. ${ }^{43}$

${ }^{43}$ Note the following contrast between Dutch (i) and German (ii):

(i) dat*(er) gelachen werdt

(ii) dass (*es) gelacht wurde that EXPL laughed was

A detailed discussion is found in Haider 2002. 
In sum, scrambling of DPs across other DPs is only possible in OV languages if the scrambled item is overtly identifiable. This accounts for the principled difference between German and Dutch. The only instances of scrambling in Dutch, therefore, involve the scrambling of ergative subjects and of PPs, the former because of their structural identification, the latter because of their identification by the lexical $\mathrm{P}^{0}$-head.

\subsection{Scrambling is Syntactically Optional. ${ }^{44}$}

In the preceding sections, scrambling is characterized as the option of "blind" A-chain formation within the V-projection: the surface order is related to the base order by antecedent-trace relations. Consequently, scrambling is allowed where syntax does not forbid it, with the base order as the default option. Viewed from this perspective, scrambling is necessarily optional in syntax. However, the degree of structural freedom offered by the grammar is exploited for a direct and overt fit at the syntax-external interfaces. Scrambling is never obligatory.

In order to make a case for obligatory scrambling, one would need a situation where only the scrambled order would be grammatical, but the base order would be deviant. Such a case could be constructed with the ban on $w h$-indefinites in the domain of particle negation (see Jacobs 1982, Haider 1996). Consider in particular the data in 55a-d and the premise that negation invariably precedes the VP. Only $55 \mathrm{a}-\mathrm{b}$ are grammatical, since indefinites do not occur in the scope of the negation particle. ${ }^{45}$ However, this premise is not reliable. Universally, negation precedes the position of the finite verb, and therefore negation precedes

\footnotetext{
${ }^{44}$ For optionality of scrambling in Japanese, see Fukui 1993, Saito and Fukui 1998:44, and Miyagawa 1997. Boskovic and Takahashi (1998) try to reconcile the optionality within a minimalist framework. Contra Saito and Fukui, they assume that scrambling involves covert movement: the scrambled element is base generated in its overt non-theta-position and is moved in LF to the position where it receives its theta-role. This hypothesis is motivated primarily by the desire to find a consistent way of integrating optional scrambling into minimalism, even at the expense of assuming lowering rules. We interpret this as a demonstration of the obvious difficulties of acknowledging an optional system potential rather than offering a convincing solution.

${ }^{45}$ Instead, a negative indefinite form is used (for example, nobody instead of not someone).
} 
the VP in VO languages. ${ }^{46}$ But in OV languages (such as German and Dutch), the verb position is the lowest position in the VP, so the negation can be placed close to verb within the VP (see Haider 1997c). Hence, the most plausible account is that the indefinites in 55 are base-generated in their overt position but nevertheless precede the negation.

(55) a. dass hier wer was nicht begreift that here who what not grasps 'that someone does not grasp something here'

b. dass er hier Gesindel nicht duldet that he here rabble not tolerates 'that he does not tolerate rabble here'

c. *dass hier wer nicht was begreift that here who not what grasps

d. *dass er hier nicht Gesindel duldet that he here not rabble tolerates

To be precise, the account sketched above does not presuppose that the negation particle may never precede indefinite arguments. This would be inadequate, given the following examples.

(56) a. Sie muss nicht Frösche/*wen an die Wand nageln. she must not frogs/ someone to the wall nail 'she needs not nail frogs/someone onto the wall'

b. Sie muss Frösche nicht an die Wand nageln. she must frogs not to the wall nail

c. */??Sie nagelt nicht Frösche an die Wand. she nails not frogs to the wall

${ }^{46}$ Since the position of a negative particle is a position that c-commands the finite verb or its trace, such a particle in the role of sentence negation cannot appear in a VP-internal position in a VO language:

(i) He has talked gently to Mary.

(ii) *He has talked never to Mary.

(iii) *He has talked not to Mary.

However, in an OV language, the negation particle occurs VP-internally, since any VP-internal position c-commands the finite verb in its base position (see also Jacobs 1982). 
The negation particle is a scopal element. In 56a the position of the negation marks the scope domain of the negated modal. In the absence of the modal, this position is not acceptable (see 56c). Since the negation operates on the domain of existential closure, an indefinite preceding negation cannot be interpreted as existentially bound: in 56c, the frogs are interpreted generically.

In sum, the examples above are representative of a more general fact. The claim that scrambling is obligatory would require data that, beyond any doubt, would demonstrate the existence of an element in a fixed structural position above the VP that is obligatorily preceded by the scrambled object. There is no evidence for this being the case in German or Dutch.

\subsection{Scrambling Can Apply to More Than One Phrase.}

In contrast to movement to Spec positions, which is limited to one constituent in the uncontroversial instances (for example, Spec,C in V2 languages), scrambling is not limited in this respect. In 57, we insert a particle between the two fronted objects in order to rule out a multipleSpec analysis.

(57) dass sein neues Auto $_{i}$ ja seiner Freundin ${ }_{j}$ Peter $\left(e_{i} e_{j}\right)$ nicht that his new car PRT his girlfriend Peter not anvertraute trusted-with 'that Peter did not trust his girlfriend with his new car'

In 57 two objects have been scrambled to positions preceding the subject (note the scrambling of the subject in 50). The absence of relativized minimality or economy effects (procrastinate or shortest path) follows if, as we assume, the head of a scrambling chain is in an adjunction rather than a substitution configuration. There is no competition for a single position triggered by some feature.

\subsection{Scrambled Elements are Possible Binders and Give Rise to Scope Ambiguities.}

Scrambling of a potential binder creates new binding possibilities. This fact holds for principle-A effects $(58 \mathrm{a}, \mathrm{b})$ as well as for Q-binding of pronouns (58c). In 58a, the binder (Männer 'men') does not c-command the bindee. Scrambling of the binder (58b) yields a well formed c- 
command configuration. In 58c scrambling is a prerequisite for a well formed Q-binding dependency.

(58) a. *dass man einander $\mathrm{i}_{\mathrm{i} / \mathrm{DAT}}$ die Männer $_{\mathrm{i} / \mathrm{ACC}}$ vorstellte that one each-other the men introduced

b. dass man die Männer ${ }_{j}^{i}$ einander ${ }^{i} e_{j}$ vorstellte that one the men each-other introduced 'that one introduced the men to each other'

c. dass man fast jeden ${ }_{\mathrm{i} / A C C}^{\mathrm{i}}$ seinem $^{\mathrm{i}} \operatorname{Vorgesetzten}_{\text {DAT }} \mathrm{e}_{\mathrm{i}}$ that one almost everyone his boss ankündigte announced 'that almost everyone was announced to his boss'

These examples demonstrate that binding applies at the target position of scrambling and not at the respective base positions, hence no reconstruction. This distinguishes scrambling-chains from $\mathrm{A}^{\prime}$-chains such as topicalization constructions; compare the examples in 59.

(59) a. Aneinander ${ }_{i}^{\mathrm{i}}$ hat man die Bilder ${ }^{\mathrm{i}} \mathrm{e}_{\mathrm{i}}$ angeglichen. to-each-other has one the pictures assimilated 'The pictures were made to look similar to one another.'

b. *[Aus Peters ${ }^{\mathrm{i}}$ Wagen $]_{\mathrm{j}}$ hat man ihn ${ }^{\mathrm{i}} \mathrm{e}_{\mathrm{j}}$ gezerrt out-of Peter's car has one him pulled

Reconstruction, that is, application of the binding principles at the foot position of the A'-chain, guarantees well formed binding in 59a and is responsible for the deviance of $59 \mathrm{~b}$ with a coreferent construal. For scope ambiguities resulting from scrambling, see section 3.3.2. 


\section{Is Yiddish a Scrambling OV language? Yes!}

\subsection{General Remarks.}

That Yiddish displays scrambling phenomena is uncontroversial. What is controversial, however, is whether Yiddish is a VO or an OV language, that is, whether the Yiddish V-projection is head-initial or head-final. If it is head-initial, as has been emphasized by Diesing (1997), our claim that scrambling is incompatible with VO languages would be contradicted. ${ }^{47}$

The complicating aspect for Yiddish is the fact that nominal arguments precede or follow the (non)finite verb. The examples in 60 are taken from Diesing 1997:402. She assumes 60a to reflect the base order of the VP. 60b-d are the results of scrambling to the left of the Vprojection. If Yiddish were an OV language, the overt order in $60 \mathrm{c}$ would be the base order, and 60d a scrambling order. 60a,b, however, would need a different account: either arguments may move to the right, or verbs move to the left. We argue for an $\mathrm{OV}$ base configuration with optional V-movement to the left.

(60) a. Maks hot nit gegebn Rifken das bukh.

Max has not given Rebecca the book

'Max did not give Rebecca the book.'

b. Maks hot Rifken ${ }_{i}$ nit gegebn $e_{i}$ dos bukh.

Max has Rebecca not given the book

c. Maks hot Rifken ${ }_{i}$ dos bukh ${ }_{j}$ nit gegebn $e_{i} e_{j}$.

'Max has Rebecca the book not given

d. Maks hot dos bukh Rifken $_{i}$ nit gegebn $e_{i} e_{j}$.

Max has the book Rebecca not given

\footnotetext{
47 Analogously, if a Slavic language like Russian were justly viewed as a "consistently" VO language, we would have to inelegantly stipulate in our account to allow for scrambling in some VO languages. Although we cannot embark on the question as to whether Russian is consistently VO, nor on the comparison of the scrambling phenomenon in German and Russian, we take Yiddish and Hindi as exemplary cases for the existence of languages that are neither consistently VO nor consistently OV languages, and we hope that this holds for so-called "Slavic VO" languages too. After all, Yiddish does also share other features with Polish and Russian (for example, multiple $w h$-fronting).
} 
Diesing's main argument is the well known discourse effect of scrambling: the preverbal position is preferred for "strong" 48 construal DPs, whereas "weak" ones come after the verb (Diesing 1997:390). This, in combination with the assumption that the VP is the domain of existential closure (Diesing 1992), is the basis for the conclusion that the definite preverbal DPs are moved out of the VP.

As discussed above (section 5.2.1), we contest the second premise. If, as we assume, the domain of existential closure is the MAC, the preverbal DPs may still be inside the V-projection, but scrambled out of the MAC. A sufficient assumption for the specificity facts under discussion would be that the verb has raised to the left edge of the MAC. This is what we claim. The unspecific indefinites get bound under existential closure in the MAC, specific DPs are scrambled and thus end up preceding the verb. Compare the examples in 61.

(61) a. Maks hot [Rifken ${ }_{\mathrm{i}}$ nit $\left[\right.$ gegebn $_{\mathrm{j}}\left[\mathrm{e}_{\mathrm{i}}\right.$ ken bukh $\left.\left.\left.\mathrm{e}_{\mathrm{j}}\right]\right]\right]$. Max has Rebecca not given any book. 'Max did not give any book to Rebecca.'

b. Maks hot [dos bukh ${ }_{i}$ nit [gegebn ${ }_{j}\left[\right.$ ken yingl $\left.\left.e_{i} e_{j}\right]\right]$

Max has the book not given any boy.

'Max did not give the book to any boy.

If this is the correct analysis, it follows that the preverbal arguments in surface order must have been scrambled, and that Yiddish is just one of the scrambling OV languages with one additional property though, namely, extensive V-fronting within a VP-shell structure, a property independently ascertained for Hindi (Mahajan 1997).

In order to reiterate and strengthen our account we refer readers to Vikner 2001 for an extensive and thorough treatment of the fundamental question whether Yiddish is a VO or an OV language. We fully accept Vikner's (2001) painstakingly argued conclusion that the evidence for Yiddish as underlyingly OV is robust and straightforward. We briefly review the main data areas; see Vikner 2001 for more examples and their sources.

48 "Strong" basically refers to definite, specific, or generic interpretations, while "weak" is intended to describe existentially bound indefinites. 


\subsection{Null Objects under Coordination.}

Following Sadock 1998, Vikner shows in detail that the possibility in Yiddish of certain coordination constructions with an empty second object is most easily accounted for if the base order in Yiddish is the same as in German, namely OV. Note the preverbal location of the (italicized) pronominal object in the Yiddish example in 62a (from Sadock 1998:222, 225) and its counterpart in German (62b). 63c shows the difference between Yiddish (and German) and English, a VO language, which does not allow an empty second object under coordination.

(62) a. Di yidene hot aroysgenumen eyn gandz the woman has out-taken one goose ... un (zi) avekgeleygt af'n tish. and it down-put on-the table 'The woman took out one goose and put it down on the table.'

b. Die Frau hat eine Gans herausgenommen the woman has one goose out-taken und (sie) auf den Tisch gestellt and (it) on the table put

c. The woman took out a goose and put *(it) on the table

\subsection{Separable and Inseparable Verb Particles.}

Vikner (2001:37) characterizes the relevant facts of (in)separable verb particles as follows: "In Yiddish and the (other) Germanic OV languages, particle verbs whose particles are postverbal under V2 nevertheless always have preverbal particles in non-V2 contexts, whereas in the Germanic VO languages, particle verbs whose particles have to be stranded under V2 never have preverbal particle in non-V2 contexts."

Only if Yiddish is an OV language like German and Dutch, and not a VO language like English or Scandinavian, does it follow straightforwardly that Yiddish allows such particles to occur preverbally in non-V2 constructions that do not incorporate. Contrast the examples from German $(63 a, b)$ and Yiddish $(63 c, d)$ with those from Danish $(63 \mathrm{e}, \mathrm{f})$. In each sentence the particle is italicized. 
(63) a. Wann kommt der Zug an? when comes the train PRT 'When is the train arriving?'

b. *Wann ankommt der Zug? when PRT-comes the train

c. Ven kumt der tsug on? when comes the train PRT

d. *Ven onkumt der tsug? when PRT-comes the train

e. *Hvornår kommer toget an? when comes the-train PRT

f. Hvornår ankommer toget?

when PRT-comes the-train

6.4. Obligatory Lack of Agreement on Predicate Adjectives.

Yiddish, like the OV languages German, Frisian, and Dutch, has inflected attributive adjectives, but uninflected predicate adjectives, whereas those VO languages that have inflected attributive adjectives (that is, all Scandinavian and Romance languages) also have inflected predicate adjectives. None of the present-day OV languages has predicate adjective agreement. Vikner (2001) argues that the directionality in the VP (OV vs. VO) corresponds to the directionality in the AP, yet another reason for assigning Yiddish to the group of $\mathrm{OV}$ Germanic languages. The data in 64 are from Dutch; these parallel the Yiddish data in 65. The examples in 66 are the Swedish translations of 65 ; note especially the difference between $65 \mathrm{~d}$ and $66 \mathrm{~d}$. Inflectional endings are italicized. " $\varnothing$ " denotes a null suffix on attributive adjectives and the absence of a suffix on predicate adjectives.

(64) a. een groene bus / twee groene bussen

a green-MASC/FEM.SG bus two green-PL buses

b. een groen $\phi \quad$ huis / twee groene huizen

a green.NEUT.SG house two green-PL houses

c. Een bus is groen $\phi$

a/one bus is green

d. Twee bussen zijn groen $\phi$

two buses are green 
(65) a. a griner oytobus /tsvey grine oytobusn

a green-MASC.NOM.SG bus two green-PL buses

b. a grin $\phi$ hoyz / tsvey grine hayzer

a green-NEUT.SG house two green-PL houses

c. Eyn oytobus iz grin $\phi$

one bus is green

d. Tsvey oytobusn zaynen grin $\phi$

two buses are green

(66) a. en grön $\phi$ bus / två grön $a$ bussar

b. ett grönt hus / två grön $a$ hus

c. en bus är grön $\phi$

d. två bussar är gröna

The examples in 67 from French illustrate the Romance pattern of agreement with the predicate.

(67) a. Les soldats $s_{\mathrm{i}}$ sont $\left[\mathrm{vP}_{\mathrm{i}} \mathrm{t}_{\mathrm{i}}\right.$ morts $\left.\mathrm{t}_{\mathrm{i}}\right]$.

the soldiers are died-MASC.PL

'The soldiers died/are dead.'

b. Les victimes $s_{i}$ sont $\left[{ }_{v P} t_{i}\right.$ mortes $\left.t_{i}\right]$

the victims are died-FEM.PL

'The victims died/are dead.'

6.5. Variation in (Nonfinite) Verb Sequences (Verb Clusters, Verb Projection Raising).

In terms of word order patterns for sequences of nonfinite verbs, the VO languages show no variation whatsoever, but the OV languages vary very much, with Frisian being the only of nine Germanic OV languages showing no variation at all. Yiddish would be exceptional within the VO group but fits very well into the OV group. It shares the verb word order of German plus the variation that derives the Dutch order from the German basic order (see Haider 2003). Note, however, that there is no Germanic VO language that shows anything similar. Hence, Yiddish is once again a well behaved OV Germanic language in this respect. The sentences in 68 and 69 illustrate the verb-auxiliary order in passive constructions, while 70 and 71 present the contrasts in causatives. For an exhaustive overview for all verb constructions, see Vikner 2001. 
(68) a. *Dos hoyz iz gevorn opgebrent.

[Yiddish] the house is become up-burned

[German]

b. Das Haus ist abgebrannt worden

[Yiddish]

c. Dos hoyz iz opgebrent gevorn. the house is up-burned become 'The house was burned down.'

(69) a. The book will be bought.

b. *The book will bought be.

c. Bogen vil blive købt. book-the will become bought

[Danish]

d. *Bogen vil købt blive book-the will bought become

The patterns found in passive constructions are representative for other analytic constructions, such causatives, formed with let-verbs; cf. 70 and 71.

(70) a. He has let us wait.

b. *He has wait let us

c. Han har ladet os vente.

[Danish]

he has let us wait

d. *Han har os vente ladet.

(71) a. Er hot undz gelozt vartn. he has us let wait

[Yiddish]

b. Er hot undz vartn gelozt.

c. Hij heeft ons laten wachten.

[Dutch] he has us let wait

d. *Hij heeft ons wachten laten.

e. *Er hat uns lassen warten. he has us let wait

f. Er hat uns warten lassen.

[German]

On the basis of the sufficiently extensive, robust, and diverse evidence, and in combination with the scrambling property, Vikner (2001:86) concludes that it is obvious "that an account of Yiddish as an 
OV language will have far less problems to deal with than an account of Yiddish as a VO language would."

What is specific about Yiddish is its status as an OV language with VP-internal V-raising. This is not an isolated phenomenon. Yiddish is simply an example of a head-final language with both $\mathrm{V}$-fronting in the V-projection and scrambling. A language with exactly these properties, namely Hindi, has already been analyzed by Mahajan (1997). Investigations of c-command-sensitive properties reveals that postverbal arguments in the VP in Hindi are not right-adjoined but more deeply embedded than preverbal ones. On the basis of this evidence, Mahajan concludes that the postverbal position is the result of $\mathrm{V}$-fronting, rather than of moving DPs to the right.

In sum, we fail to see compelling evidence for a $\mathrm{VO}$ analysis of Yiddish. An empirically and theoretically more satisfactory analysis assumes a basic OV structure for the Yiddish V-projection plus Vfronting. We conclude, therefore, that Yiddish is unproblematic for the claim that scrambling is a characteristically OV phenomenon.

\section{Summary.}

In the foregoing, we have defended the following seven points.

First, scrambling is chain-formation in the extendable projection of a head-final projection of a lexical head, that is, scrambling is adjunction within or to the MAC. The head of the scrambling chain is therefore in the identification domain of the verbal head, while the foot of the chain is located in the base position, thereby rendering the scrambling chain an A-chain. Scrambling correlates with headedness, since the headedness direction interacts with identification. Scrambling, defined in this way, is not found in VO languages, the reason being that left-adjunction to a VO structure creates a position that is not in the identification domain of the head of the projection. As a welcome consequence, therefore, our analysis also offers support for the assumption that OV cannot be derived from VO.

Second, only elements with a unique base position, that is, selected elements, can be said to scramble.

Third, scrambling chains come into being only when the surface order differs from the base order, that is, scrambling cannot be string-vacuous.

Fourth, from the first claim it follows that scrambling is syntactically optional, clause-bound, category neutral, and may be applied to more than one phrase. 
Fifth, scrambled elements are possible binders and take scope, and they remain transparent for extraction.

Sixth, scrambling is a free system potential that is exploited at the semantic and information structure interface levels of syntax. We argued that our approach is superior to counterproposals at least on the level of empirical adequacy. Scrambling is not just freely base-generated word order, nor is it the output of movement that targets functional Spec positions. Since scrambling is only possible in cases where the base order of the selected constituents may be identified by nonpositional, morphological case-checking, Dutch, although an OV language, does not allow the rearrangement of argumental DPs. Scrambling of PPs across DPs, however, is possible.

Seventh and finally, our conclusion that scrambling is only possible in $\mathrm{OV}$ languages is tested on Yiddish, a truly scrambling language. We arrive at the conclusion-contrary to recent claims - that Yiddish is an $\mathrm{OV}$ language whose apparent $\mathrm{VO}$ patterns are the result of V-fronting.

\section{REFERENCES}

Adger, David. 1994. Functional heads and interpretation. Doctoral dissertation, University of Edinburgh.

Aoun, Joseph, and Yen-hui Audrey Li. 1993. Syntax of scope. Cambridge, MA: MIT Press.

Boskovic, Zeljko, and Daiko Takahashi. 1998. Scrambling and Last Resort. Linguistic Inquiry 29.347-366.

Broekhuis, Hans. 2000. Against feature strength: The case of Scandinavian object shift. Natural Language and Linguistic Theory 18.673-721.

Chomsky, Noam. 1995. The minimalist program, Cambridge, MA: MIT Press.

Chomsky, Noam. 1998. Minimalist inquiries: The framework. (MIT occasional papers in linguistics, 15.) Cambridge, MA: MIT Department of Linguistics and Philosophy.

Chomsky, Noam. 1999. Derivation by phase. (MIT occasional papers in linguistics, 18.) Cambridge, MA: MIT Department of Linguistics and Philosophy.

Cinque, Guglielmo. 1999. Adverbs and functional heads. A cross-linguistic perspective. (Oxford studies in comparative syntax.) Oxford and New York: Oxford University Press.

Collins, Chris, and Höskuldur Thráinsson. 1996. VP-internal structure and object shift in Icelandic. Linguistic Inquiry 27.391-444. 
Corver, Norbert, and Henk van Riemsdijk. 1994. Studies on scrambling. Berlin: Mouton de Gruyter.

Corver, Norbert, and Henk van Riemsdijk. 1997. The position of the head and the domain of scrambling. Typology: Prototypes, item orderings and universals, ed. by Bohumil Palek, 57-90. (Proceedings of LP '96.) Prague: Charles University Press.

Culicover, Peter, and Michael Rochemont. 1983. Stress and focus in English. Language 59.123-165.

Delfitto, Mario, and Norbert Corver. 1997. Feature primitives and the syntax of specificity. Unpublished manuscript, Tilburg University.

Deprez, Viviane. 1994. Parameters of object movement. In Corver and van Riemsdijk (eds.), 101-152.

Diesing, Molly. 1992. Indefinites. Cambridge, MA: MIT Press.

Diesing, Molly. 1997. Yiddish VP order and the typology of object movement in Germanic. Natural Language and Linguistic Theory 15.369-427.

Fanselow, Gisbert. 1993. The return of the base generators. Groninger Arbeiten zur germanistischen Linguistik 36.1-74.

Fox, Danny. 2000. Economy and semantic interpretation. Cambridge, MA: MIT Press.

Frey, Werner. 1993. Syntaktische Bedingungen für die Interpretation (Studia grammatica, 35.) Berlin: Akademie Verlag.

Frey, Werner, and Karin Pittner. 1998. Zur Positionierung von Adverbien. Linguistische Berichte 176.489-534.

Fukui, Naoki. 1993. Parameters and optionality. Linguistic Inquiry 14.399-420.

Geerts, Guido, W. Haeseryn, J. de Rooij, and M. C. van den Toorn. 1984. Algemene nederlandse spraakkunst. Groningen: Wolters-Noordhoff.

Grewendorf, Günther, and Joachim Sabel. 1999. Scrambling in German and Japanese. Adjunction versus multiple specifiers. Natural Language and Linguistic Theory 17.1-65.

Gussenhoven, Carlos. 1984. On the grammar and semantics of sentence accents. Dordrecht: Foris.

Haegeman, Liliane. 1998. Verb movement in embedded clauses in West Flemish. Linguistic Inquiry 29.631-656.

Haider, Hubert. 1984. The case of German. Studies in German grammar, ed. by Jindrich Toman, 65-102. Dordrecht: Foris.

Haider, Hubert. 1992. Branching and discharge. Arbeitspapiere des Sonderforschungsbereichs 340, Universities of Stuttgart and Tübingen 23.1-31. (Reprinted 2000 in Lexical specification and insertion, ed. by Peter Coopmans, Martin Everaert, and Jane Grimshaw, 135-164. [Current issues in linguistic theory, 197.]) Amsterdam: John Benjamins.

Haider, Hubert. 1993. Deutsche Syntax generativ. Tübingen: Gunter Narr. 
Haider, Hubert. 1996. Wenn die Semantik arbeitet, —und die Syntax sie gewähren läßt. Wenn die Semantik arbeitet, ed. by Gisela Harras and Manfred Bierwisch, 7-27. Tübingen: Max Niemeyer.

Haider, Hubert. 1997a. Scrambling—Locality, economy, and directionality. In Tonoike (ed.), 61-91.

Haider, Hubert. 1997b. Projective economy: On the minimal functional structure of the German clause. German: Syntactic problems-Problematic syntax, ed. by Werner Abraham and Elly van Gelderen, 83-103 Tübingen: Max Niemeyer.

Haider, Hubert. 1997c. Economy in syntax is projective economy. The role of economy principles in linguistic theory, ed, by Chris Wilder, Hans-Martin Gärtner, and Manfred Bierwisch, 205-226. (Studia grammatica, 40.) Berlin: Akademie Verlag.

Haider, Hubert. 1997d. Precedence among predicates. Journal of Comparative Germanic Linguistics 1.3-41.

Haider, Hubert. 2000a. OV is more basic than VO. The derivation of VO and OV, ed. by Peter Svenonius, 45-67. Amsterdam: John Benjamins.

Haider, Hubert. 2000b. Adverb placement—Convergence of structure and licensing. Theoretical Linguistics 26.95-134.

Haider, Hubert. 2002. Mittelfeld phenomena. The syntax companion (Syncom), ed. by Martin Everaert and Henk van Riemsdijk. (Case 64.). (Available online at http://www.uilots.let.uu.nl/syncom)

Haider, Hubert. 2003. V-clustering and clause union—causes and effects. Verb constructions in German and Dutch, ed. by Pieter Seuren and Gerard Kempen, 91-126. Amsterdam: John Benjamins.

Haider, Hubert, and Inger Rosengren. 1998. Scrambling. (Sprache und Pragmatik, 49.) Lund: University of Lund.

Heck, Fabian. 2000. Tiefenoptimierung: Deutsche Wortstellung als wettbewerbsgesteuerte Basisgenerierung. Linguistische Berichte 184. 441-468.

Hetland, Jorun. 1992. Satzadverbien im Fokus. (Studien zur deutschen Grammatik 43.) Tübingen: Max Niemeyer.

Holmberg, Anders, and Christer Platzack. 1995. The role of inflection in Scandinavian syntax. Oxford: Oxford University Press.

Hoop, Helen de. 1992. Case configuration and noun phrase interpretation. Doctoral dissertation, University of Groningen.

Jackendoff, Ray. 1972. Semantic interpretation in generative grammar. Cambridge, MA: MIT Press

Jacobs, Joachim. 1982. Syntax und Semantik der Negation im Deutschen. (Studien zur theoretischen Linguistik, 1.) Munich: Wilhelm Fink.

Kayne, Richard. 1994. The antisymmetry of syntax. Cambridge, MA: MIT Press. 
Kayne, Richard. 1998. Overt versus covert movement. Syntax 1.128-191.

Koch, Wolfgang, and Inger Rosengren. 1995. Secondary predications: Their grammatical and conceptual structure. (Sprache und Pragmatik, 35.) Lund: University of Lund.

Kress, Bruno. 1982. Isländische Grammatik. Munich: Hueber Verlag.

Larson, Richard. 1988. On the double object construction. Linguistic Inquiry 19.335-391.

Lenerz, Jürgen. 1999. Word order variation: Competition or co-operation? Unpublished manuscript, University of Cologne.

Mahajan, Anoop. 1994. Toward a unified theory of scrambling. In Corver and van Riemsdijk (eds.), 301-330.

Mahajan, Anoop. 1997. Against a rightward movement analysis of extraposition and rightward scrambling in Hindi. In Tonoike (ed.), 93-124.

Maienborn, Claudia. 1996. Situation und Lokation-Die Bedeutung lokaler Adjunkte von Verbalprojektionen. (Studien zur deutschen Grammatik, 53.) Tübingen: Stauffenburg Verlag.

Miyagawa, Shigeru. 1997. Against optional scrambling. Linguistic Inquiry 28.1-25.

Müller, Gereon. 1995. A-bar Syntax. Berlin: Mouton de Gruyter.

Müller, Gereon. 1998. Incomplete category fronting: A derivational approach to fronting and movement. (Studies in natural language and linguistic theory, 42.) Dordrecht: Kluwer.

Müller, Gereon. 1999. Optimality, markedness, and word order in German. Linguistics 37.777-818.

Müller, Gereon. 2000. Elemente der optimalitätstheoretischen Syntax. Tübingen: Stauffenburg Verlag.

Neeleman, Ad. 1994. Scrambling as a D-Structure phenomenon. In Corver, and van Riemsdijk (eds.), 387-429.

Neeleman, Ad. 1995. Complex predicates in Dutch and English. Studies in comparative Germanic syntax, ed. by Hubert Haider, Susan Olsen, and Sten Vikner, 219-240. Dordrecht: Kluwer.

Neeleman, Ad, and Tanya Reinhart. 1997. Scrambling and the PF interface. Projecting from the lexicon, ed. by Mark Cobler and Miriam Butt. Stanford: CSLI.

Neeleman, Ad, and Fred Weerman. 1999. Flexible syntax — a theory of case and arguments. Dordrecht: Kluwer.

Pesetsky, David. 1994. Zero syntax: Experiencers and cascades. Cambridge, MA: MIT Press.

Postal, Paul. 1993. Parasitic gaps and the across-the-board phenomenon, Linguistic Inquiry 24.735-754.

Rochemont, Michael. 1986. Focus in generative grammar. Amsterdam John Benjamins. 
Rosengren, Inger. 1993. Wahlfreiheit mit Konsequenzen-Scrambling, Topikalisierung und FHG im Dienste der Informationsstrukturierung. Wortstellung und Informationsstruktur, ed. by Marga Reis, 251-312 (Linguistische Arbeiten, 306). Tübingen: Max Niemeyer.

Rosengren, Inger. 1994. Scrambling-Was ist das? Was determiniert Wortstellungsvariation?, ed. by Brigitta Haftka, 175-196. Opladen: Westdeutscher Verlag.

Rosengren, Inger. 2000a. EPP and the post-finite expletive, Working Papers in Scandinavian Syntax 65.1-34.

Rosengren, Inger. 2000b. Rethinking the adjunct, ZAS Papers in Linguistics 17.217-240.

Rosengren, Inger. 2002. EPP: A syntactic device in the service of semantics, Studia Linguistica 56.145-190.

Rosengren, Inger. 2003. Clause-final left adjunction. Modifying adjuncts, ed. Ewald Lang, Claudia Maienborn, and Catherine Fabricius-Hansen, 335-362. (Interface explorations 4.) Berlin: Mouton de Gruyter.

Ross, John. 1967. Constraints on variables in syntax. Doctoral dissertation, MIT.

Ruys, E. G. 2001. Dutch scrambling and the strong-weak distinction. Journal of Comparative Germanic Linguistics 4.39-67.

Sadock, Jerrold 1998. A vestige of verb final syntax in Yiddish. Monatshefte 90.220-226.

Saito, Mamoru, and Naoki Fukui. 1998. Order in phrase structure and movement. Linguistic Inquiry 29.439-474.

Sauerland, Uli. 1999. Erasability and interpretation. Syntax 2.161-188.

Selkirk, Elisabeth. 1984. Phonology and syntax: The relation between sound and structure. Cambridge, MA: MIT Press.

Tonoike, Shigeo (ed.). 1997. Scrambling. (Linguistics workshop series, 5.) Tokyo: Kurosio Publishers.

Uhmann, Susanne. 1991. Fokusphonologie. (Linguistische Arbeiten, 252.) Tübingen: Max Niemeyer.

van den Wyngaerd, Guido. 1989. Object shift as an A-movement rule. MIT Working Papers in Linguistics 11.256-271.

Vikner, Sten. 1994. Verb movement and expletive subjects in the Germanic languages. (Oxford studies in comparative syntax.) Oxford: Oxford University Press.

Vikner, Sten. 2001. Verb movement variation in Germanic and optimality theory. Habilitation thesis, University of Tübingen.

Webelhuth, Gert. 1992. Principles and parameters of syntactic saturation, (Oxford studies in comparative syntax.) Oxford: Oxford University Press.

Winkler, Susanne. 1997. Focus and secondary predication, Berlin and New York: Mouton de Gruyter. 
Wunderlich, Dieter. 1997. Cause and the structure of verbs, Linguistic Inquiry 28.27-68.

Yip, Moira, Joan Maling, and Ray Jackendoff. 1987. Case in tiers. Language 63.217-250.

Zubizarreta, Maria Luisa. 1998. Prosody, focus and word order. Cambridge, MA: MIT Press.

Institut für Sprachwissenschaft

Universität Salzburg

Mühlbacherhofweg 6

A-5020 Salzburg

Austria

[hubert.haider@sbg.ac.at]

Tyska Institutionen

Lunds Universitet

Helgonabacken 14

S-223 62 Lund

Sweden

[inger.t.rosengren@telia.com] 